\title{
HERVORMD AS KERKNAAM GEHANDHAAF
}

\section{INLEIDING}

Dit was Ds. Frans Lion Cachet, die stigter van die Ned. Gereformeerde Kerk in Transvaal in 1866, wat die eerste van die naam van die Kerk in Suid-Afrika 'n twisappel gemaak het. Hy was soos 'n Esau. Sy hand was teen almal en almal se hand was teen hom. Hy het Transvaal deurreis en orals waar hy kom, het hy moeilikheid verwek en die mense opgemaak teen die Hervormde Kerk. Die naam Hervormd sou dan onwettig wees. Dit sou dan Ned. Geref. moet wees. Op hierdie wyse het die twis oor die naam ontstaan. Tevore is altwee name gebruik en was daar geen moeilikheid daaromtrent nie. Omdat volgens Cachet die naam Hervormd dan onwettig sou wees, het die stryd ontbrand. Die een het dit opgeneem vir Hervormd, die ander vir Gereformeerd.

Hierdie onverkwiklike getwis word nou weer deur Dr. H. S. Pretorius, argivaris van die Ned. Herv. of Geref. Kerk, voortgesit, nl. om alles wat Hervormd genoem word, te ontken waar enigsins moontlik, en waar dit nie moontlik is nie, dan dit te probeer doodpraat.

In die tweede helfte van verlede jaar het daar tussen Dr. Pretorius en my ' $n$ pennestryd ontstaan in Die Vaderland.

Hy het twee artikels geskryf en ek twee; die tweede uit my pen het in Die Hervormer verskyn (Jan. 1953), omdat die diskussie toe reeds in Die Vaderland gesluit was.

Omdat Dr. Pretorius, soos uit die strekking van sy geskrifte duidelik blyk, nieteenstaande al sy vrome betuigings die Hervormde Kerk geen plek onder die son gun nie, daarom kon hy dit by sy twee artikels nie laat nie. Uit sy pen het toe weer twee artikels in Die Kerkbode oor die naam van die Kerk verskyn. Ook dit was nog nie vir hom genoeg nie. Hierdie twee artikels is ,in 'n meer uitgebreide vorm" gepubliseer in 'n brosjure onder die titel: .Die Kerknaam. Antwoord aan Ds. Joh. Dreyer (en Prof. S. P. Engelbrecht)". Prof. Engelbrecht word dus ook hierby ingesleep en in die voorlaaste hoofstuk word 'n beledigende aanval op hom gemaak. Ook Dr. T. S. van Rooyen, van die Universiteit van Pretoria, kry in die laaste hoofstuk 'n beurt. Hy het dit immers ook gewaag om vir Hervormd op te kom en Dr. Pretorius se toorn daarmee opgewek. Hierdie laaste hoofstuk is getitel: „Antwoord op 'n teregwysing deur Dr. T. S. van Rooyen". 
Omdat ek nie mag nalaat dat die Hervormde Kerk in sy historiese reg van bestaan deur Dr. Pretorius te na gekom word nie en ook omdat ek sy onjuisthede nie onweerspreek mag laat nie, daarom skryf ek hierdie stuk. Ek wil aantoon dat sy "nooit" wat die naam „Hervormd" betref, onjuis is. Hy beweer immers dat die Voortrekkers ,hulle Kerk nooit anders ${ }^{1}$ ) as (Ned.) Gereformeerd genoem het nie"; dat die Natalse .Volksraad die Kerk nooit anders as (Ned.) Gereformeerd genoem het nie"; ${ }^{2}$ ) dat ,, die Voortrekkers vandat hulle die Kolonie verlaat het, nooit die benaming Hervormd vir hulle Kerk gebruik het nie." ${ }^{3}$ )

Omdat Dr. Pretorius agter hierdie soort „nooit-deur" staan, soek hy my ook daar en as hy dan een of ander dokument kry, wat vir die naam Geref. pleit, soos byvoorbeeld dat Ds. van der Hoff ook soms die naam (Ned.) Geref. vir die Kerk gebruik, dan vra hy ewe triomfantelik: Sal Ds. Dreyer dit ontken? of iets dergeliks. So 'n vraag is nie nodig nie, en wel om die eenvoudige rede dat ek nooit ontken het dat die naam (Ned.) Gereformeerd ook deur Ds. van der Hoff en die Voortrekkers gebruik is. Waar hy en ek in die grond van die saak verskil, is waar ek sê: én ... én, nl. dat die naam (Ned.) Geref. én die naam Hervormd gebruik is, daar sê hy nooit . . . nóóit, behalwe dat hy dan teen wil en dank tog 'n enkele uitsondering moet maak, maar dan tog weer probeer om met 'n omhaal van woorde en redenering dit so gering moontlik te maak soos bv. met die .,kollektelysie" van 1841 .

As 'n mens 'n ander nie ook 'n plekkie gun nie en jy staan by die groot meerderheid, dan is die gevolg van hierdie houding dat jy ongeduldig, onvriendelik en smalend word as jy teengepraat word. Dit vind ons by Dr. Pretorius. Teenoor dié wat met hom verskil, gebruik hy sulke smalende onvriendelikhede soos "kleinlik", "onwaardig", „onsin", „kerkisme", „treuriger en sielloser redenering", .,klug", "fiasko", „onbenullig", en dan ongeveer 'n halfdosyn keer .,propaganda geskryf".

'n Paar keer het hy al laat uitkom dat ek argiefwerk nog nooit sou gesien het nie - weer "n "nooit" - terwyl hy 'n argivaris is. In sy brosjure is die blyke van sy argiefwerk egter maar skraal. Ek sou my maar net op Prof. S. P. Engelbrecht beroep. Maar volgens sy brosjure beroep hy hom egter veral op Dr. Scholtz, Dr. van Jaarsveld, Ds. Fick, Ds. Spoelstra.

Een van die onjuishede van Dr. Pretorius waarteen ek ernstig beswaar wil aanteken, is sy bewering dat hy in 1949 'n stuk vir publikasie in Die Hervormer aan my gestuur het en dat ek sou geweier het

1), 2) en 3) Die Vaderland, 6 Oktober 1952. 
om dit te plaas. Dit is ' $n$ halwe waarheid. Waarom vertel hy nie die hele waarheid nie, of waarom publiseer hy nie my brief aan hom nie? In antwoord op sy brief om sy stuk te plaas, het ek hom geskryf dat ek dit wél sal plaas, maar onder voorwaarde dat hy sal sorg dat 'n stuk van my oor dieselfde saak in Die Kerkbode opgeneem sal word. Op hierdie wyse sou sy mense dan ook nie net een kant van die saak hoor nie. Op hierdie brief het Dr. Pretorius egter nooit geantwoord. My voorwaarde wou hy dus nie aanneem nie. My artikel mog toe nie in Die Kerkbode kom nie. Met watter reg kan hy dan eis dat sy artikel wel in Die Hervormer moet kom?

Sy veel-geroemde argiefwerk en sy hantering van die bevinding van Dr. Besselaar in Die Afrikaner van 11 Maart 1927 gaan ook nie op nie. In sy artikel in Die Vaderland van 6 Oktober 1952 het Dr. Pretorius geskryf :

„dat die Voortrekkers vandat hulle die Kolonie verlaat het, nooit die benaming, "Hervormd" vir hulle kerk gebruik het nie, behalwe in die meer vermelde kollektelys van 1841 . Nieteenstaande 'n aantal lidmaatsertifikate in hulle besit met die benaming "Hervormd" daarop (die meerderheid van die sertifikate ket ongetwyfeld die benaming "Gereformeerd" daarop gehad - vergelyk die bevinding van prof. Besselaar in die Afrikaner van 11 Maart 1927) het hulle hulle kerk steeds (Ned.) Gereformeerd genoem. Hierdie feit sal niemand ontsenu nie".

Hierdie ,argiefwerk" van Dr. Pretorius het ek gekontroleer en wat is my bevinding? Ek het dit gegee in my artikel in Die Hervormet van Januarie 1953. Daar staan:

,Met .Die Afrikaner' van 11 Maart 1927 in die hand wil hy dan voorgee dat die Voortrekkers in Natal steeds hulle Kerk (Ned.) Gereformeerd genoem het. Hy wat skimp oor die bronnestudie van ander, hoe staan dit met syne? Die bevinding van prof. Besselaar in ,Die Afrikaner' van 11 Maart 1927 bewys presies die teenoorgestelde van wat Dr. Pretorius beweer. Prof. Besselaar wys juis daarop dat die Pietermaritzburgse gemeente volgens die gemeente se eie argief twaalf (sic!) verskillende name het".

En wat doen Dr. Pretorius in sy brosjure waarin hy tweemaal op hierdie punt terugkom? Erken hy dat hy sy lesers verkeerd ingelig het? Moenie glo nie. Met 'n stortvloed van woorde wil hy dit probeer omseil. Hy gebruik 84 reëls daarvoor. Dis byna twee bladsye, waarin ek beskuldig word, egter sonder bewyse, dat ek sy sinne en woorde uit verband sou ruk en dat ek hom in die mond sou lê wat hy nie bedoel 
of geskryf het nie. Verder beroep hy hom in hierdie 84 reëls weer op Dr. Scholtz dat die naam „Hervormd" in die Noorde uit Holland ingevoer sou wees. Al verontskuldiging wat hy aanvoer vir sy onjuiste voorligting, is dat toe hy van lidmaatsertifikate gespreek het, sou hy dit dan per abuis verwar het met hierdie voorbeelde van Prof. Besselaar.

Maar in hierdie lange redenering om by sy fout verby te kom, begaan hy 'n volgende onjuistheid. Hy skryf:

..Let wel, volgens die lys van Prof. Besselaar is die eerste gebruik van die naam Hervormd in Natal uit die jaar 1850 en wel deur Ds. van Velden wat pas aangekom het uit Holland".

Dr. Pretorius begin die sin met: „Let wel", maar as 'n mens wel oplet, dan blyk dit juis dat voor 1850 en voor die Hollander, Ds. van Velden, in Natal was, het die Kerkraad van Pietermaritzburg hulself reeds genoem: "Nederduitsch Hervormde Gemeente alhier” en wel in 1838 of 1839 .

'n Tweede keer gebruik Dr. Pretorius die woordjies: „Let wel" en maak ' $n$ tweede bewering wat net so onjuis is as die eerste. Hy skryf: „Let wel, dit is nie die Kerk of gemeente wat homself Hervormd noem nie, maar individue". Maar hy wat werklik goed oplet, sal juis merk dat dit ook nie korrek is wat Dr. Pretorius hier beweer nie. Onder die vyf gevalle, deur Prof. Besselaar genoem, waar die woord Hervormd voorkom, is daar nie een deur los persone of individue nie, maar almal juis deur offisiële persone van die gemeente van Pietermaritzburg self. Hierdie stuk van Prof. Besselaar word verder in hoofstuk 4 van hierdie stuk afgedruk. Punt twee van die lys nl. 'n bladversoekskrif „vanwege den kerkeraad der Nederduitsche Hervormde Gemeente alhier", en die twee kwitansies nl. punte 8 en 11 kan alleen deur die skriba van die kerkraad, dus in offisiële hoedanigheid, gedoen gewees het. Dit geld ook wat punt 6 betref, want alleen die skriba en miskien ook die predikant en as sodanig die voorsitter van die kerkraad, sal al die besonderhede hê van die 53 lidmate nl. deur wie, waar en op watter leeftyd hulle aangeneem is. As offisieël moet ook beskou word punt 12 nl. die brief van oudl. Ferreira, wat tog immers ' $n$ ampsdraer van die gemeente was.

Dr. Pretorius probeer altyd om by sulke feite verby te kom bv. deur te sê, dat die Voortrekkers as georganiseerde gemeenskap ${ }^{4}$ ) op een uitsondering na (die kollektelys op Potchefstroom in 1841 opgestel) hul Kerk nooit anders as Ned. Gereformeerd of slegs Gereformeerd

1) Die Kerknaam bls. 7. In Die Vaderland van 6 Oktober 1952 ontbreek die gekursiveerde woorde. Om sy standpunt van 6 Oktober houdbaar te probeer maak, is die woorde in die brosjure bygevoeg. 
genoem het nie". Met hierdie slinger van „as georganiseerde gemeenskap" om sy arm, probeer hy dan om sy stelling te versterk, maar die gevalle, waar die kerkraad van Pietermaritzburg's) self van Hervormd praat, dié sien hy ondanks sy eie "let wel" nie raak nie.

'n Ander punt waarop gereageer moet word is die naamsverandering aan die Kaap in 1842. Dr. Pretorius sê dat ek ,tot vervelens toe gehamer" het op die woord ,,verander". Dat hy dit vervelend vind is duidelik, want hy kan met al sy redeninge hier nie verby kom nie. Daar staan nou eenmaal nie soos hy en sy meestaanders dit graag wil hê nie. Dr. T. N. Hanekom spreek van vas lê van die mees gangbare naam in 1842. (Vgl. Die Kerkbode 21 Februarie 1951, bls. 401); Dr. G. D. Scholz skryf dat die ou naam Gereformeerd in 1842 ,herbevestig is" (Vgl. Jaarboek van die N.G. Kerke 1952, bl. 177) en van die verandering in die Vrystaat skryf hy: „In 1865 is op versoek van die Vrystaatse sinode die naam van die Kerk in die konstitusie reg aangegee as Nederduitsch Gereformeerd" (Vgl. Die Voorligter bls. 52).

Dr. H. S. Pretorius skrywe i.v.m. 1842 dat „die ou historiese kerknaam herbevestig word". (Al die kursiverings van die woorde: vas lê, herbevestig, reg aangegee, is van my).

Maar wat sê die notule van die Sinode self? Nié „vas lê" nie. nie ,herbevestig" nie, nie ,reg aangee" nie, maar "verander".

Dr. Pretorius se poging om by die woord ,verander" verby te kom, is nie geslaag nie. Hy beweer, op die voetspoor van Dr. Scholtz. dat die naam van die Kerk op 2 November 1842 in Art. 1 herbevestig is tot Ned. Gereformeerd en dat op 5 November in Art. 14 die naam van Ned. Hervormd verander is in Ned. Gereformeerd om in ooreenstemming met Art. 1 te wees.

Dit kon so gewees het as Art. 1 altyd Ned. Geref. was, maar dit is juis nie so nie. Art. 1 het gelui :-

.,Tot het Hervormd Kerkgenootschap behooren allen, die op belijdenis des geloofs tot ledematen zijn aangenomen, dezulken die in de Hervormde Kerken gedoopt zijn, en degenen, die in andere landen als tot het Hervormd Kerkgenootschap behoorende erkend ...."

In die notule van die vergadering staan daar:

„Door den Wel-Eerw. H. Morrees werd voorgesteld, dat men in de plaats van Art. 1 te lezen zoo als gedrukt is, leze „,tot het

5) Sien hoofstuk 4.

6) Vgl, O.a. ook Handleiding vir die Kerkgeschiedenis deur Prof. Dr. S. du Toit, bls. 149 . 
Nederduitsch Gereformeerde Kerkgenootschap behooren allen die op belydenis des geloofs tot lidmaten zijn aangenomen".

Ds. Moorrees het dus reeds by Art. 1 voorgestel dat die naam van die Kerk verander word van Hervormd in Gereformeerd.

Op 5 November het hy dieselfde gedoen ${ }^{7}$ ) as op 2 November en hier staan duidelik die woord verander in die notule. Die feit dat twee lede van die Sinode nl. Dr. A. Faure en Ds. J. J. Brink beswaar gemaak teen die verandering van die naam, is ' $n$ bewys dat dit nie maar net die herbevestiging van die naam Ned. Gereformeerd was nie, maar 'n daadwerklike verandering. Natuurlik was dit 'n verandering, gesien die feit dat die mees offisiële en die mees sekure dokument van die Kerk, nl. sy eie Kerkwet van 1824, die Kerk tot in 1842 steeds Nederduitsch Hervormde Kerk noem.

Die Hollanders sou volgens Dr. Pretorius verantwoordelik wees vir die naam Hervormd vir die Kerk, maar die Hollander ${ }^{8}$ ) Erasmus Smit en die Hollander Ds. Huet en die Hollander Ds. Frans Lion Cachet gebruik juis die naam (Ned.) Gereformeerd en in die begin het ook die Hollander Ds. van der Hoff, onder die invloed van die Kaap waar hy gelegitimeer is, die woord Ned. Gereformeerd gebruik, totdat die Voortrekkers hom anders geleer het.

Die Hollander Groenendaal het wel die Vrystaatse konstitusie en die Hollander Stuart dié een van die Zuid-Afrikaansche Republiek opgestel, maat hulle werk is deut die betrokke kommissies wat nie uit Hollanders bestaan het nie, sowel as deur die twee betrokke Volksrade goedgekeur. En met hierdie daad het hulle ook voorkeur gegee aan die naam Hervormd bo Gereformeerd. Met hierdie feite is dit tog onmoontlik om nog vol te hou dat alleen 'n Hollander verantwoordelik is vir die naam Hervormd. Hierdie feite kan nie ontken word nie, maar Dr. Pretorius skrywe dat soos ek dit stel „,is om die minste daarvan te sê uiters onverantwoordelik".

As die Kerk in die Vrystaat dan tot in 1867 Hervormd was, en die naam toe eers in Ned. Geref. verander is, ,het Ds. A. Murray dan van 1849-60 'n Hervormde gemeente op Bloemfontein bedien?" so vra Dr. Pretorius. Hy redeneer hier soos die toestand in 1953 is en nie soos dit 'n honderd jaar gelede was nie. Toe was dit moontlik dat 'n Ds. Cachet in dieselfde brief homself konsulent van die Hervormde Gemeente van Utrecht genoem het en in die betrokke stuk ook die naam Ned. Gereformeerd gebruik. Toe was dit moontlik dat predikante tussen 1842 en 1873 die akte van ondertekening as Hervormde

7) De Handelingen der Zeven eerste Vergaderingen van de Alg. Synode der Ned. Geref. Kerk van Z.A., bls. 197 v.v.

8) Die Voortrekkers en hul Kerk deur Eerw. A. Dreyer bls. 20. 
predikante onderteken, maar om predikante in die Ned. Geref. Kerk te word. Toe was dit moontlik dat die kerkraad van Pietermaritzburg sowel as ander kerkrade, verskillende name vir hulself gebruik, waaronder Ned. Hervormd en ook Ned. Geref.

\section{In dieselfde trant as hierbo vra Dr. Pretorius:}

.Waarom het Ds. Dreyer nie aan sy lesers voorgehou dat die Vrystaatse gemeentes (saam met die Natal) die Kaapse Sinode tot in 1862 bygewoon het nie? Hoe kon .,Hervormde" gemeentes die Sinode van 'n Ned. Gereformeerde Kerk bywoon?"

Op hierdie selfde manier kan ek aan Dr. Pretorius vra: hoe kan bv. die predikante Dr. P. E. Faure, wat die Ondertekeningsakte van aankomende predikante van die "Ned. Hervormde Kerk" in 1834 en Dr. A. Murray wat dit in 1848 onderteken het, tog sitting neem in die Sinode van die Ned. Geref. Kerk?

Indien daar 'n Hervormde gemeente in 1842 op Potchefstroom gestig is, waarom, so vra Dr. Pretorius, is in 1853 tot die naam Ned. Geref. teruggekeer? Ons antwoord: Ds. van der Hoff het hierdie naam in die Kaap gekry, dit in die begin in Transvaal gebruik, maar die volk het, soos met sy eie konstitusie blyk, voorkeur gegee aan die naam waarmee hulle uit die Kaap gekom het en Ned. Hervormd gebruik.

Die kerklik-historiese bronne van die Hervormde Kerk sou dan volgens Dr. Pretorius vir die bona fide navorser nie toeganklik wees nie. Maar Dr. Gerdener het insae gehad van die Potchefstroomse registers vgl. sy „Boustowwe vir die Geskiedenis van die Ned. Geref. Kerk in die Transgariep" (1930 bls. 185). Ek veronderstel dat Dr. Pretorius hierdie werk van Dr. Gerdener ken waarin sy bewering weerlê word. Ook ander persone het insae gehad, en die staatsargief in Pretoria besit selfs ' $n$ fotografiese kopie van die ou doopregisters van Potchefstroom van 1842-1850. Iedereen kan maar daarna gaan kyk en dan sal hul sien dat daar van die bewerings van Dr. Pretorius in hierdie verband geen woord van waar is nie. Dr. Pretorius sê dat aan hom insae geweier sou wees. Waarom weet ek nie. Miskien is hy nie as ' $n$ bona fide navorser beskou nie. As mens let op die lelike en ergerlike beskuldigings wat hy op bls. 492 van Die Kerkbode van 15 April 1953 maak, beskuldigings wat aan laster grens, dan is dit wel begryplik. Blykbaar het hy dit self as lasterlik beskou, want op bls. 11 van sy brosjure, het hy in deel daarvan weggelaat. In Die Kerkbode het hy as volg geskryf :

.,In 1942 het ds. M. L. Fick my persoonlik meegedeel dat hy in 1889 hulpprediker op Potchefstroom was van ds. C. W. du Toit 
J. G. M. Dreyer, Predikant van die Nederduits Hervormde Gemeente, Potchefstroom, van die Nederduits Hervormde Kerk van Afrika, aan my voorgelê is om na te gaan en hierdie sertifikaat uit te reik, en nadat ek die betrokke twee omslae of boekdele noukeurig en presies nagegaan het, kan ek as volg sertifiseer :-

1.

Buite op die harde omslag van die eerste deel is 'n stuk papier geplak waarop gedruk staan: „Doop Register Nr. 127 Maart 1842 - 24 Dec. 1849."

2.

Dat op die harde omslag van die tweede boekdeel of register ook 'n stuk papier geplak is waarop gedruk staan: „Doop Register Nr. 2, 24 Dec. 1849 - 1 Dec. 1850."

3.

Dat die eerste doop register die name van die kinders wat gedurende die tydperk 27 Maart 1842 tot 24 Desember 1849 in die Transvaal gedoop is, bevat, met die geboortedatum, die doopdatum, die name van die ouers en die name van die doopgetuies. Die inskrywings is gedoen op dubbele folio-papier en wel so dat twee bladsye folio-papier, d.w.s. die linker- en die regter bladsy as een bladsy gemerk is. Op die linkerbladsy staan die naam van die dopeling, die geboortedatum, en die doopdatum terwyl op die regter-bladsy dan staan die name van die ouers en van die doopgetuies. Die folio-papier is nie deurgaans dieselfde nie en later is daar gebruik gemaak van 'n ander soort papier. Die gehele deel 1 bevat 104 sulke dubbele bladsye en dit is duidelik dat hierdie bladsye toe later in 'n boekvorm ingebind is sodat dit die genoemde Register nr. 1 uitmaak en dat verdere bladsye saamgebind is in Register nr. 2.

4.

Dat by die nagaan van die eerste register dit duidelik blyk dat die eerste bladsy besig was om te verweer en stukkend te gaan en daar is toe 'n ander folio-blad op die agterkant geplak om sodoende die eerste bladsy te versterk. Die laaste bladsy is soortgelyk op die agterkant ook toegeplak. Die papier waarmee die eerste- en die laaste bladsye aan die agterkant toegeplak is, is dun folio-papier en as mens dit teen die lig hou dan kan duidelik gesien word dat op die toegeplakte agterkant van die eerste bladsy alleen die woorde .,Doop Register No. I" gestaan het terwyl 
wat later met die grootste gedeelte van die gemeente uit die Verenigde Kerk terug gekeer het tot die Hervormde Kerk. Onderwyl Ds. du Toit met agt maande verlof na Europa was, het Ds. Fick die registers in sy bewaring gehad, en op die buiteblad (of voorblad) daarvan het, soos hy beweer, die naam Ned. Gereformeerd voorgekom. Hy het dit ook in die kerkblad De Vereeniging vermeld. Dit het ek in my stuk wat op 5 September in Die Vaderland verskyn het, genoem.

Ds. D. antwoord hierop dat ek op hoor-sê áfgaan en ontken kortweg die bewering van ds. Fick. Ds. D. sal nog moet leer om te onderskei tussen die inhoud van hoor-sê en 'n eerstehandse mededeling van 'n gesiene persoon soos ds. Fick. Alles wat nie by sy redenering pas nie verwerp hy as onwaar. Dan vermeld hy van die uitstalling, tydens die eeufees in 1942, van die ou registers van die gemeente en skryf dat ook leiers van die N.H. of G. Kerk dit ,besigtig' het, en vra dan of hulle sou geswyg het, ,as die wens-bewering van ds. Fick waar was?"

Die registers was onder ds. D. se beskerming; hy het seker die uitstalling gereël. Sal hy vir ons sê (1) waarom die doopregister in 'n glaskas uitgestel was; (2) waarom insae daarin aan een van ons kerkleiers geweier is deur die opsigter; (3) waarom die voorblad van die doopregister toegeplak was; (4) waarom 'n wenk van die genoemde leier om dit "los te maak" (of te ontbloot) met stilswye deur die opsigter beantwoord is? Voorwaar 'n wonderlike manier van doen vir iemand wat 'n sterk saak het! (Ek het meer as een getuienis in hierdie verband swart op wit)"

Ek wil ook hier ernstig protes aanteken teen hierdie laakbare insinuasies van Dr. Pretorius. Sou hy nie weet waarom eintlik die eeuoud, verweerde dokumente in glas uitgestal is nie? Moet hy nieteenstaande al sy betuigings van goeie gesindheid teenoor die Hervormde Kerk en sy lidmate, sulke oneerlike motiewe daaragter soek? Die verklaring wat hier volg van 'n kommissaris van ede en regsgeleerde laat al sy verdagmakende bewerings van oneerlikhede in duie stort sowel as die uit die lug gegrepe bewerings van Ds. Fick:

\section{Notariele Sertifikati.}

Ek, die ondergetekende,

\section{Willem Lodewyk van Eck}

van Pretoria, Transvaal, Notaris Publiek, as sodanig beëdig en toegelaat en praktiserende te Pretoria, Transvaal, sertifiseer hiermee dat sekere twee boeke gebind in 'n swart omslag deur Ds. 
op die agterkant van die laaste bladsy heeltemal niks geskryf was nie. Dat al wat dus toegeplak is, is die aangehaalde woorde "Doop Register Nr. I" en verder is daar niks hoegenaamd toegeplak nie.

5.

Dat dit verder ook duidelik is dat die dun folio-papier wat gebruik was om die bladsy een aan die agterkant te versterk 'n opening gelaat het en in die opening is daar toe die woorde ..Doop Register Nr. I" geskryf. Dat daar dus niks toegeplak is om enige woorde, opskrifte, ens. onleesbaar te maak nie.

6.

Dat die dubbele bladsye 1 tot 40 die name bevat van kinders wat deur Ds. Lindley op 27 Maart 1842, 30 Mei 1844, 3 Junie 1844 en 8 Junie 1844 gedoop is. Dat onderaan hierdie name staan ..Deze bovenstaande zijn gedoopt door den Eerwaarde Heer Ds. Iintlee". Onderaan die voet van die bladsy waarop hierdie sertifikaat voorkom is daar nog ' $n$ doopnaam ingeskryf van iemand wat op 20 Mei 1845 gedoop is, maar daar word nie gemeld deur wie hierdie persoon gedoop is nie.

7.

Dat op die dubbele-bladsye 41 tot 66 die name van die kinders wat op 10,16, 18 en 19 April 1848 gedoop is verskyn. Dit word nie gesê deur wie hulle gedoop is nie.

8.

Dat daar op die dubbele bladsy 66 die volgende sinsnede of sertifikaat verskyn: „Gedoopt door de Commissie der Hoog Eer waarde Synode bestaande uit de Predikanten P. E. Faure en Wm. Robertson de volgende kinderen:" en dan volg op die dubbelebladsy 66 tot 93 die name van die kinders wat op 17,21, 23 en 24 Desember 1848 deur P. E. Faure en W. Robertson gedoop is.

Dat op die dubbele-bladsy 93 die volgende sertifikaat voorkom : .,Gedoopt door ons gecommitteerd van wege de Hoog Eerw. Synode der Nederduitsche Gereform. Kerk in Zuid-Africa". Dat direk na hierdie sertifikaat daar die handtekeninge van die predikante P. E. Faure en William Robertson volg.

9.

Op die dubbele-bladsy 94 tot 104 volg die name van 180 kinders wat op 10,13,17 en 24 Desember 1849 gedoop is, en met hierdie laaste inskrywing van 24 Desember 1849 eindig die eerste ingebonde deel wat gemerk is as .Doop Register Nr. I." 
10.

Dat daar nêrens in hierdie register of in Doop Register No. 2 die naam van die Gemeente van Potchefstroom nóg die naam Hervormd nóg die naam Gereformeerd voorkom behalwe in die sinsnede wat op die dubbele-bladsy 93 verskyn dat die betrokke persone ,gecommitteerd" was vanweë die „Hoog Eerwaarde Synode der Nederduitsche Gereformeerde Kerk in Zuid-Africa".

11.

Die tweede „Doop Register" wat gemerk is soos reeds hierintevore gesertifiseer bestaan uit 36 dubbele folio bladsye en is ook net soos die eerste deel ingebind in 'n harde omslag met die woorde "Doop Register Nr. 2" 24 Dec. 1849 - 1 Dec. 1850" voorop gedruk.

12.

Dat ook die eerste bladsy in hierdie deel op die agterkant met 'n dun stuk folio papier toegeplak is, om dit blykbaar te versterk. Dat dit duidelik is, as dit teen die lig gehou word, dat daar hoegenaamd niks toegeplak is nie.

13.

Dat op die folio papier wat op die blanko-agterkant van die eerste blad geplak is alleen die woorde "Doop Register Nr. 2" geskryf staan in ink.

14.

Dat hierdie deel die vervolg vervat van name van kinders wat op 24 Desember 1849 gedoop is en verder die name van gedooptes op 31 Desember $1849,11,13,14,15$ en 21 Januarie 1850 , en verder op 21, 22, en 27 Oktober, 27 November en 1 Desember 1850.

15.

Dat nêrens in hierdie register die naam van 'n Kerk voorkom nie en dat daar ook nêrens verwys word na Gereformeerd of Hervormd nie.

Aldus gedoen en geteken te Pretoria op hierdie 18de dag van Augustus 1953.

Quod Attestor :

W. L. van Eck, Notaris Publiek.

2/ Inkomsteseel gerojeer deur die Notaris op 18/8/1953. 
Of Dr. Pretorius sy growwe beledigings sal terugtrek en of hy daarmee sal voortgaan, elke keer egter weer vergesel van vrome betuigings teenoor die Hervormde Kerk en sy lidmate, moet ons afwag. Sy taak is volgens hom dan ook so belangrik want soos hy die verloop van die geskiedenis stel is dit objektief en korrek, soos verdedigers van die naam Hervormd dit stel is dit subjektief en apoligeties, na die woorde van Dr. van Jaarsveld wat hy onderskryf.

Die Kerkbode en ook Die Voorligter is of vir die twisappel oor die kerknaam, wat Dr. Pretorius na Ds. Cachet weer aan die rol gesit het, moeg, of miskien reken hulle dat op die brosjure van Dr. Pretorius oor die kerknaam niks te sê is nie.

In Die Kerkbode van 5 Augustus 1953 skryf T. N. H(anekom) immers : „Ons meen dan ook dat hierdie saak nou afgehandel is, wat ons Kerk betref", en Die Voorligter skryf in sy Augustus-uitgawe: "Dit (die brosjure oor die kerknaam) bied 'n verrassing, en kan wellig as die laaste woord oor die saak beskou word".

Hulle wat opkom vir die goeie reg van Hervormd as kerknaam, ontsê aan die voorstanders van die naam Gereformeerd nie hulle goeie reg nie en ontken ook nie die goeie historiese feite wat, soos vir die naam Hervormd, ook vir die naam Gereformeerd pleit nie, maar kom net op teen die ,nooit-nooit houding" wat teen die naam Hervormd ingeneem word en sal ook voortaan daarteen opkom.

\section{Die Naam van die Kerk in Nederland.}

Wat die naam van die ou historiese Kerk van Nederland betref. skrywe Dr. Pretorius :

„Ek herhaal : die benaming Hervormde Kerk was in Holland lank na Van Riebeeck se tyd nog gladnie in gebruik nie".9)

In die „Kerkbode" word hierdie standpunt van Dr. Pretorius as volg weergegee:

„Dr. Pretorius kom tot die gevolgtrekking dat die naam „Hervormd" voor 1775 heeltemal ongekend was." ${ }^{10}$ )

So seker is Dr. Pretorius blykbaar van sy foutiewe stelling dat hy twee uitdagings aan my rig. Die eerste is:

9) Die Vaderland, 5 September 1952.

10) Die Kerkbode, 5 Augustus 1953. 
.Sal ds. Dreyer ' $n$ enkele voorbeeld noem waar die historiese Kerk in Nederland in die 16de en $17 \mathrm{de}$ eeu met die spesifieke naam Hervormd genoem is?"'11)

En die tweede uitdaging is :

„Sal hy (Ds. Dreyer) een of meer Nederlandse skrywers noem wat saam met Prof. Engelbrecht beweer dat die Kerk in Nederland voor 1796 nie 'n naam gehad het nie?"'12)

Albei uitdagings neem ek graag aan. Voor 1796 net een naam: Gereformeerde Kerk! Hervormd "gladnie in gebruik nie"! ,heeltemal onbekend" voor 1775! En dan is Dr. Pretorius selfs met 'n enkele voorbeeld tevrede!

Ek sal hom nie net een noem nie, maar 'n lange lys van baie voorbeelde wat sy stellings weerspreek. $\mathrm{Ek}$ sal begin met homself. $\mathrm{Hy}$ self gee sulke voorbeelde. Dan sal ek die sub-redakteur van sy eie kerkblad gebruik om hom te weerspreek en dan bewyse van sinodes en van 'n reeks van skrywers noem.

In sy brosjure ${ }^{13}$ ) haal hy met instemming aan in geval waar die Kerk in Nederland voor 1775 en ook voor 1796 Hervormd genoem word:

,n Voorbeeld ('n ingediende remonstransie - op 2 Julie 1790) waarin die naam Hervormde Kerk voorkom."

Dit word nog mooier as hy daar verder byvoeg:

..Voorts word vermeld dat in die ,Dagverhalen van de Nationale Vergadering' herhaaldelik sprake is van ,hervormd Kerkgenootschap', .gereformeerd kerkgenootschap' en ,hervormde kerkgemeenschap" ter aanduiding van die Kerk in sy geheel".

Hierdie aanhalings waarmee Dr. Pretorius instemming betuig, het hy van die Ryksargivaris uit Nederland ontvang. En dan voeg hy (Dr. Pretorius) by sy aanhalings nog by :

„Dit word bevestig in die werk van Dr. J. Th. de Visser ,Kerk en Staat' Deel III bl. 73-78 wat ek persoonlik nageslaan het." ${ }^{{ }^{14}}$ )

11) Die Vaderland, 6 Oktober 1952.

12) Die Kerknaam, bls. 5. Die kursivering is van my.-Joh. D.

13) Die Kerknaam, bls. 19.

14) Die Kerknaam, bis. 19. 
Maar as mens hierdie deur Dr. Pretorius genoemde bladsye in die boek van Dr. de Visser naslaan, dan sien mens dat daarin presies die teenoorgestelde gesê word as wat $\mathrm{Dr}$. Pretorius aan sy mense vertel wat daar sou gesê word. So lees ons bv. op bls. 73 :

.Wie de Dagverhalen der nationale vergadering doorleest, vindt dat van de Kerk als geheel elk oogenblik de woorden hervormd genootschap', ,gereformeerd genootschap', ,gereformeerde kerkgenootschap', ,hervormde kerkgemeenschap', ,christelijk-godsdienstig genootschap der hervormden' gebezigd".

En op bls. 75:

,Zoo vinden wij ... gesproken van ,de gedeputeerden van de respective kerkenraaden der Nederduitsche Hervormde Gemeente binnen dat gewest (Utrecht)' of van de voorrechten welke de Hervormde Kerk boven alle overige Kerkgemeenten in ons Vaderland tot hiertoe genoot."

Die woorden tot hiertoe wat deur my gekursiveer word, beteken vóót die Rewolusie van 1795. Dit is werklik 'n raaisel hoe Dr. Pretorius hom op die ryksargivaris en Dr. de Visser wil beroep. Laat Dr. Pretorius tog eers behoorlik lees wat daar staan, voordat hy hom vir sy standpunt op stukke beroep waarin hy juis weerspreek word. Verder haal Dr. Pretorius met instemming die volgende uit die brief van die Ryksargivaris uit Nederland aan :

.In die slotparagraaf word dan vermeld dat daar destyds geen eenheid in naamgewing was nie en dat die name Hervormde Kerk en Gereformeerde Kerk mekaar afwissel." (Kursivering deur my. Joh. D.)

Dit is dus presies wat ons beweer nl. dat vóór die Napoleontiese tyd, toe alle Kerke nog nie voor die wet gelykgestel was nie, die ou historiese Kerk in Nederland van ná die Kerkhervorming nie een vaste naam gehad het nie, maar met verskillende name aangedui is soos Hervormde Kerk, Gereformeerde Kerk, ens.

Ook waar Dr. Pretorius met instemming Prof. P. J. Muller aanhaal, bevestig hy juis ons standpunt dat voor 1796 die Kerk by meer as een naam bekend was. Prof. Muller skryf dat:

„voor 1816 gewoonlijk van de Gereformeerde Kerken in de Nederlanden" gespreek is. 
"Gewoonlijk", dus nie 'n vaste naam nie. Beteken hierdie voorbeelde deur Dr. Pretorius self genoem dan nie dat hy teen beterwete in beweer, dat die Kerk vanaf die dae van die Kerkhervorming net een vaste naam gehad het? Hy hou ook hier 'n slinger om sy arm en sê dat hy "nergens" beweer het „dat die naam Gereformeerd die offisiële naam van die Kerk in Nederland vóór 1816 was nie. Deur usansie was dit geyk as die naam van die Kerk". ${ }^{15}$ ) Hier erken hy dus dat ons standpunt korrek is, dat die kerk destyds geen of fisiële, vaste naam gehad het nie!!

Dr. Pretorius wil juis Nederlandse skrywers genoem hê wat leer dat voor 1796 die Nederlandse Kerk nie 'n vaste naam gehad het nie. Dr. T. N. Hanekom, die sub-redakteur van Die Kerkbode, die offisiële orgaan van die Ned. Gereformeerde Kerke, is nou wel geen Nederlander nie, maar tog leer ook hy dit. In sy uitgawe van 21 Februarie 1951 skryf Dr. Hanekom as volg oor hierdie aangeleentheid:

„Om te sê dat die Kerk aan die Kaap aanvanklik nie juis 'n offi siële naam ontvang het nie, het min betekenis hier. In Nederland het die Moederkerk tog ook geen eenvormige offisiële naam in daardie jare gehad nie en kry ons ook willekeurig aanduidinge soos ,Gereformeerde Kerken', ,Christelijk Gereformeerde godsdienst' en "Hervormde Kerk'."

En verder :

,Dit sou maklik wees om talryke voorbeelde uit Nederland tussen die jare 1665-1816 (en later) aan te haal om te bewys dat ook daar geen eenvormigheid in die naam van die Kerk was nie". (Kursivering van my. Joh. D.)

Dit leer ook prof. J. I. Marais in sy „Geschiedenis der Ned. Geref. Kerk in Zuid Afrika" bls. 27. Daar skryf hy:

„Prof. Schaff, een kenner der Kerkgeschiedenis met wie men rekenen moet, heeft verklaard, dat het aantal martelaren in de Nederlandse Hervormde Kerk groter was dan van enige Protestantse Kerk in de zestiende eeu ... Jaren lang droegen de hervormde gemeenten de eigenaardige naam van ,De Nederlandsche Kerk en die onder het Cruis zitten'."

Dr. Pretorius se eie kerkmense stem dus nie met hom saam nie. Sedert die dae van die Kerkhervorming is verskillende name vir die Kerk in Nederland gebruik soos: ${ }^{16}$ )

15) Die Kerknaam, bls. 19.

16) Die Hervormer van 29 Mei 1935: „Die Hervormde Kerk in Nederland" deur Ds, Joh. Dreyer. Sien ook Die Hervormer van 27 Jan. 1937. 
„de Nederlandsche Kerk(en)"; ,de Nederlandsche Kerken die onder het kruis zitten"; "de Gereformeerde Kerk(en)"; ,"de Hervormde Kerk"; „de Nederduitsche Gereformeerde Kerk"; „de Nederduitsche Kerk", ens.

Talle bewyse is daar wat ons vir Dr. Pretorius kan noem dat die Kerk in Nederland in die 16 de en 17 de en tot naby die einde van die 18 de eeu geen vaste naam gehad het nie. So gebruik die Acta van die Sinode van Emden in 1571 die naam:

„De Nederlandsche Kercken die onder't Cruys sitten".

Die Acta van die Nasionale Sinode van Middelburg in Nederland in 1581 noem die eerste kerkordening: „Kerkordeninghe inden generalen Synodo der Nederlandtsche Kercken". In die eerste uitgawe van die Nederlandse Geloofsbelydenis in 1562 word die Nederlandse Kerk nie met 'n bepaalde naam genoem nie. In die eerste Nederlandse uitgawe van die Heidelbergse Kategismis 1562 dra die Kerk ook geen naam nie, terwyl in die uitgawe van 1580 gepraat word van "ghereformeerden Evangelische Kercken". Let wel, ,gereformeerden" is hier nie 'n selfstandige naamwoord nie maar 'n byvoeglike naamwoord net soos „nederduits" by „Nederduits Hervormd” en by „Nederduits Gereformeerd". As hier dus van 'n eie naam sprake sou wees, dan sou dit wees „Evangelische Kerkcken". In die uitgawe van 1565 dra die Kerk ook nie ' $n$ eie naam nie, net so min as in die van 1610 wat op las van die sinode van Zeeland deur Hermanus Faukelius uitgegee is.

In die Acta van die Sinode van Dordrecht 1618-1619 kom weer 'n ander naam voor nl.: „Gereformeerde Kerken". Drie agtereenvolgende Sinodes het dus drie verskillende name gebesig vir dieselfde ou historiese Kerk.

Maar Dr. Pretorius wil juis graag name van Nederlandse skrykers hê, wat ook die standpunt toegedaan is, dat die Kerk voor 1796 nie 'n eie, vaste naam gehad het nie. Met genoeë voldoen ons aan sy versoek.

In 1705 het die bekwame beoefenaar van die Nederlandse Kerkgeskiedenis, Ds. Jacobus Leydekker, twee lywige boekdele die lig laat sien teen die Remonstrant G. Brandt onder die titel „Eere van die Nationale Synode van Dordregt". Dit was "n werk van jare lange studie en daarin is die name Hervormd en Hervormde Kerk naas Gereformeerde Kerk skering en inslag. In die voorspraak van sy boek lees ons van ,den Hervormden godsdienst", maar op bls. 274 van die 2de deel beskuldig hy die Remonstrante dat hulle 'n "nieuwe Gereformeerde Kerk" wil oprig, op bls. 109 van die eerste deel spreek hy die wens uit, dat "de leeringen der Remonstranten buiten onze Hervormde Kerk blijven." 
Die bekende historikus $P$. C. Hooft gebore op 16 Maart 1581 wie se hoofwerk ..Nederlandsche Historien" is, gebruik baie die naam Hervormd vir die Kerk van sy tyd, hoewel hy ook van die Kerk as Gereformeerd spreek.

'n Ander bekende skrywer wat Hervormd naas Gereformeerd gebruik is Justus van Effen gebore op 21 Februarie 1684.

In sy "Geschiedenis der Christelijke Kerk" gebruik die historikus $F$. van Kooy albei name willekeurig vir die Kerk.

In die derde druk bls. 320 en 321 gebruik hy Hervormd en Gereformeerd om die beurt. Van Johannes a Lasco skryf hy b.v.:

„In 1540 ging hy naar Emden, de verblyfplaats van vele om het geloof vervolgde Nederlanders ... In laatst genoemde betrekking regelde hij het Hervormd Kerkbestuur van Oost-Friesland".

Van die werk van Guy de Bray, die opsteller van die Nederlandse Geloofsbelydenis, skryf hy:

„Deze geloofsbelijdenis, vervat in 37 artikelen, is een meesterstuk uit die dagen. Alle punten waaromtrent de hervormden zich te verdedigen hadden, worden klaar en duidelijk uiteengezet; en het stuk is daarom voor ons te belangrijker, omdat het de belijdenis is, waarop de Gereformeerde kerk rust".

Hierdie willekeurige gebruik van albei name vir die Kerk kom ook elders in sy werk voor. Ons noem nog een voorbeeld. Op bladsy 331 handel hy oor die Sinodes van Wessel 1568 en van Emden 1571 en van Dordrecht 1574 en dan vervolg hy:

„Een nog inniger band, die de Hervormde kerken samenbond, vormde haar belijdenis".

Op die volgende bladsy lees ons egter van: "Gereformeerde leeraren", en van "Hervormden" wat in Holland en Zeeland die meerderheid van die bevolking uitgemaak het. Verder dat "Gereformeerden om hun godsdienst niet bemoeilikt zouden worden", en twee reëls verder dat "de hervormden buiten de stad godsdienstoefeningen mochten houden", (d.w.s. buite Amsterdam in die beginjare van die Kerkhervorming).

Ook die bekende Nederlandse historikus Groen van Prinsteret gebruik die twee name Hervormd en Gereformeerd vir die Kerk in Nederland vanaf die kerkhervorming langs mekaar en deurmekaar en toon daarmee dat die Kerk toe nog nie een vaste naam gehad het nie.

In sy .,Handboek der Geschiedenis van het Vaderland" skryf hy op bladsy 84-85: „Ook in Nederland werd de Hervormde Kerk gevestigd op de belydenis van den Drie-eenigen God". 
„De Hervormde Kerk was het middelpunt en de kern van het Gemeenebest". ,In Nederland was de Hervormde Kerk de bevoorregte en heerschende Kerk". Dit gaan hier oor die tyd net na die Hervorming. Twee bladsye verder dan skryf hy van die "Gereformeerde Kerken" en van die "Gereformeerde volksgeloof" en van die "Gereformeerde volk", waarmee hy nog dieselfde Hervormde Kerk en Hervormde mense bedoel.

Ook Prof. Dr. H. G. Kleyn in sy "Algemene Kerk en Plaaslijke Gemeente" steun Dr. Pretorius nie, dat die Kerk in Nederland voor die helfte van die 18 de eeu gladnie Hervormd genoem is nie. Inteendeel, hy skrywe gewoonlik van die Gereformeerde religie, maar van die Kerk van dié tyd self gebruik hy beurtelings Hervormd en Gereformeerd. Op bls. 30 skryf hy o.a.: „Hebt gy dan nooit gelezen .... dat men oudtijds volkomen terecht sprak van de Nederlandsche, de Fransche Kerken, terwijl de uitdrukking Gereformeerde kerk onbekend was als benaming van het Kerkverband der Gereformeerde kerken .... ?" Met instemming haal Prof. Kleyn dan Hermanus Witsius aan in sy "Twist des Heeren met sijn Wijngaardt" 1671, wat spreek van .,de Aansienlyckste Mannen in onse Nederlandsche Kercken en Academiën, maar gebruikt bovendien herhaaldelik de uitdrukking, onse Nederlandtsche Kercke". Ook hier dus 'n bewys van 'n gebrek aan 'n vaste, eie naam vir die Kerk. Verder gebruik Prof. Kleyn albei name vir die Kerk. Op bladsy 155 lees ons :

„Door de Groote Vergadering te s'Gravenhage werd wettig bevestig, wat feitelijk sinds 1583 bestond: de Hervormde Kerk als de eenig wettig erkende Kerk in de Nederlanden".

en op bladsy 186 :

„Het is zelfs niet waar, wat door Mr. J. C. Naber verzekerd wordt, dat de Overheid zich sinds 1628 niet meer met de Kerkleer bemoeide. Integendeel, toen er in de Hervormde Kerk weder twisten over de leer onstonden, hebben de Overheden met meer of minder goed gevolg zich daarmede bemoeid."

In die "Redelijke Godsdienst" van Willem á Brakel gebore 1635 Derde Deel, kom agterin op bls. 394 voor die „Grafschrift ter gedachtenis van den eerwaarden, hooggeleerden, vromen, godvruchtigen heer Ds. Wilhelmus á Brakel in zijn leven getrouw uitdeler der verborgenheden Gods, in de Hervormde Gemeente van Jesus Christus te Rotterdam."

Maar op die volgende bladsy staan daar: „Rouwtranen, over het afsterven van den welgeleerden heer Wilhelmus á Brakel Getrouw 
dienaar van Jesus Christus in de Gereformeerde Gemeente te Rotterdam".

Hier word dus van dieselfde gemeente in een asem gespreek van Hervormd en van Gereformeerd.

Die Nederlandse historikus $R$. Fruin gebruik op bls. 250 verskillende name vir dieselfde Kerk nl. „Nederlandsche Kerk”, "gereformeerde Kerk", „Evangelisch-gereformeerd" en ook praat hy van die Kerk as van die „Publycque Kercken deser Landen". Ook by Fruin dus geen sprake net van een naam nie. ${ }^{17}$ )

'n Ander heel bekende Nederlandse geskiedskrywer wat nie met Dr. Pretorius instem nie, maar die Kerk in Nederland voor 1796 Hervormd noem en ook Gereformeerd, dus geen eie, vaste naam nie, is Dr. H. Berkhof. In sy "Geschiedenis der Kerk" Vierde druk lees ons o.a. op bladsy 213:

„In Emden en heel Oost-Friesland werkte in die tijd de poolsche edelman Johannes á Lasco, een zwingliaansche hervormde. In 1550 noopte het Interim hem, met de nederlandsche vluchtelingen naar Londen te gaan. Wij kunnen zeggen, dat in Londen de eerste organisatie der Nederlandsche Hervormde Kerk tot stand kwam".

En op bladsy 220 :

"Zoodra de hervormde kerk in Nederland gevestigd was, wijdde zij zich vol energie aan haar taak, om het volksleven met de geest van Genéve te vervullen".

Maar op bladsy 214 bv. skryf hy van ,de gereformeerde beweging" en van "de moed der gereformeerden", waarmee hy nog met dieselfde mense en met dieselfde Kerk te doen het wat hy op ander bladsye Hervormd genoem het.

Dr. Pretorius se tweede uitdaging aan $m y$ is :

„Sal Ds. Dreyer 'n enkele voorbeeld noem waar die historiese Kerk in Nederland in die 16 de en 17 de eeu met die spesifieke naam Hervormd genoem is?"

In sy bewering dat die naam Hervormd in Nederland voor die tweede helfte van die $18 \mathrm{de}$ eeu onbekend was, volg hy op die voetspore van wyle Dr. H. S. Bosman en veral van Dr. G. D. Scholtz op wie hy meer kere steun. In sy „Een Terugblik" skryf Dr. Bosman:

„Van 1652 tot 1775 was het woord Hervormd zowel hier als in Nederland onbekend".

17) Vgl. die Jaarboek van die Gefedereerde Ned. Gereformeerde Kerk, 1952 , bls. 169 , waar Dr. G. D. Scholtz die teendeel beweer 
Dr. Scholtz skryf :

„Van die tweede helfte van die sestiende tot die tweede helfte van die agtiende eeu het die Calvinistiese kerk en godsdiens in Nederland slegs een naam geken nl. Gereformeerd".

Drie persone dus van Ned. Geref. kant wat dieselfde bewering maak. Dr. Pretorius is blykbaar tevrede met een enkele voorbeeld om die teendeel te bewys. Ek noem vir hom en Dr. Scholtz weer sommer baie voorbeelde en begin met twee Roomse skrywers. Sou hierdie Roomse bestryders van die Nederlandse Kerk dit Hervormd genoem het as die Kerk homself nie so genoem het nie? Arnout van Geluwe skryf in 1660 teen wat hy "de nieuwe hervormde Kercke" noem. En Adriaan van Woelwyck laat in 1672 'n boek verskyn „De Sonne der Geregtigheyd Schijnende in de Duysternisse van het Hervormd Christendom". Verder het Georgius Hornius „Professor der Historien in de vermaerde Academie van Leyden" in 1684 sy kerkelycke Historie, van de Scheppinge des Werelts tot 't Jaer des Heeren 1666" uitgegee waarin hy praat van die ",hervormden Gods-dienst". In 1693 het die Amsterdamse predikant Balthasar Bekker die derde deel van sy "Betoverde Wereld" uitgegee. En daarin sê hy op bls. 156 „om so de gereformeerde Kerke die men houd na Gods Woord gereformeerd, dat is hervormd te zijn". Dit is in verband hiermee interessant om mee te deel dat daar in 1689 'n boek verskyn het van Ds. Cornelius de Kranckel: „De Noodtsakelicke ware Gereformeerden Borger Buyten ende den Hervormden Kryghsman in het Leger". In 1703 het ds. Johannes D'Outrein in Dordrecht 'n redevoering gehou toe hy die professoraat daar aanvaar het waarin hy praat van "die Hervormde Kerk". En in 1738 rig die predikante en ouderlinge van Amsterdam 'n herderlike skrywe aan die gemeente met die titel „Herderlijke en Vaderlijke Brief houdende aan de Bloeijnde Hervormde Gemeente".

In 1684 verskyn uit die pen van G. Hornius: „Kerkelycke Historie" waarin hy praat van hervormde godsdiens.

$W$. Goeree in sy „Kerkelijke en Wereldlijke Historien" 1706 noem die Kerk Hervormde Kerk.

Ds. Jacobus Leydekker se boek wat in 1716 gepubliseer is, is getitel : „De Hervormde Kerk andermaal verdedigd tegen 't Pausdom".

In dieselfde jaar verskyn daar van $A$. Francken: „Kern der Christelijke Leer, dat is de waarheid van die Hervormde Godsdienst".

In 1722 publiseer R. Amelius sy: „Het licht der Waarheid doorstralende in de leer der Hervormde Kerk".

Le Long praat in sy in 1732 verskene „Boekzaal der Nederduytsche Bijbels" van "de hervormde Leere". 
Eduard Meiners noem in sy "Oostvrieschlandts Kerkelijke Geschiedenis" 1738 Henricus Brunius in 1519 die eerste hervormde predikant aldaar.

In 1725 het 'n boekie verskyn van 'n Amsterdamse Sieketrooster, Christiaan Klaarbout, oor die Heidelbergse Kategismus: „De Luister der Hervormde Kerke".

In 1768 het in twee dele verskyn 'n lywige .,Kerkelijke Geographie .... der Hervormde Kerke in ons Vaderland" van Willem Albert Bachiene "Leeraar der Hervormde Gemeente en Hoogleeraar der Sterre en Aardrijkskunde te Maastricht" waarin hy byna altyd van die Kerk as "Hervormde Kerk" praat.

In 1744 verskyn van die hand van Johannes $d u$ Vignon, ,leeraar in de Hervormde kerk te Rotterdam" sy werk: „De zuivere schriftuurlijke Geloofsleer".

In 1756 publiseer W. te Water sy „Historie der Hervormde Kerk te Gent".

In 1769 verskyn van die bekende $d s$. Appelius 'n boek getitel : „De Hervormde Leer" waarin hy die suiwere leer van die sakramente handhaaf. Op bls. 39 gee hy die besluit van die Grote Vergadering van 's Gravenhage 1651 als volg weer:

,dat zij (die State van Holland) aan den waren Hervormden Christelijken Godsdienst, zo als die in de Synode van Dordregt was vasgesteld" sal vashou.

In die "Authentique Afschrift der Psalmen" noem die Kerk homself in 1773 ,De Hervormde Kerk van Nederland".

Van die Nederlandse Geloofsbelydenis het in 1755 'n verklaring verskyn van Ds. Arnoldus Rotterdam. Hiervan het niemand anders as Dr. Abr. Kuyper 'n nuwe uitgawe besorg. Ds. Rotterdam gee 'n „Historisch Bericht nopens de Belijdenis der Hervormde Kerk en Geloofshervorming in Nederland" en daarin lees ons op bls. 17 (Kuyper-uitgawe 1914) o.a. die volgende:

.Voorts stelt men vast dat de gemeenschap van talen en het overnemen van belijdenis, de benaming van Reformés of Hervormden op de Nederlandsche gemeenten heeft doen overgaan."

En wanneer het hierdie ,heeft doen overgaan" plaasgevind? In die dae van die Kerkhervorming.

Miskien is al hierdie voorbeelde wat uit my boekery geput is en wat met die hulp van 'n goeie biblioteek nog baie aangevul kan word. genoeg om Dr. Pretorius te oortuig, dat hy hom grootliks vergis as hy skryf : 
„Ek herhaal : die benaming Hervormde Kerk was in Holland lank na Van Riebeeck nog gladnie in gebruik nie".

"Van die tweede helfte van die sestiende tot die tweede helfte van die agtiende eeu het die Calvinistiese kerk en godsdiens in Nederland slegs een naam geken nl. ,Gereformeerd"," so het Dr. Scholtz geskryf. Dat dit 'n onhoudbare stelling is, meen ek gegenoegsaam aangetoon te hê.

\section{Die Naam van die Kerk in die Kaapkolonie.}

Dr. Pretorius skryf dat:

„die benaming Hervormd omtrent honderd jaar na Van Riebeeck se landing aan die Kaap nog so goed as onbekend in Nederland was, en die geskiedskrywer wat beweer dat Van Riebeeck hierdie benaming na Suid-Afrika gebring het, verraai daardeur sy onkunde".

So seker is hy van sy bewering dat hy daar nog byvoeg:

,Ek herhaal dit hier met alle klem". ${ }^{18}$ )

In die voorafgaande hoofstuk het ek met 'n lange reeks bewyse aangetoon dat die benaming Hervormd sedert die dae van die Kerkhervorming in Nederland naas ander name gebruik is tot op die Napoleontiese tyd toe elke mens in die ryk van Napoleon en elke Kerk 'n vaste eie naam moes kry en toe is die ander name, wat ook gebruik is vir die ou historiese Kerk van Nederland, losgelaat ten gunste van die egte Nederlandse naam Hervormd.

En hierdie selfde Kerk wat nooit offisieël 'n naamsverandering ondergaan het nie, het Van Riebeeck hierheen oorgeplant. Net soos in Nederland vóór 1796 is ook hier aan die Kaap meer as een naam vir die Kerk gebruik. En dit het so voortgeduur tot met die Kerkorde van De Mist in 1804 waarin van die Kerk offisieël as Hervormd gepraat word en wat deur die Kerk self in sy eerste Sinode in 1824 as korrek bestempel is.

Prof. Dr. S. P. Engelbrecht, wat miskien meer navorsing in verband met die Suid-Afrikaanse Kerkgeskiedenis as enig iemand anders gedoen het, het in die Almanak van die Ned. Hervormde Kerk van Afrika 1952 die titelblad laat afdruk van die oudste gedrukte preek in Suid-Afrika, asook die "Approbatie" ${ }^{\prime 19}$ ) of toestemming om dit te laat druk. Die toestemming is verleen omdat die preek nie bevind is in stryd te wees met die leer van die „Herformde Kerk" nie. Hierdie

18) Die Kerknaam, bls. 5.

19) Almanak Ned. Hervormde Kerk, bls. 92. 
merkwaardige preek na aanleiding van Jesaja $45: 1-8$ is gehou op 16 Januarie 1743 aan "Cabo de Goede Hoop in Africa" deur Ds. Wilhelm van Gendt, .Bedienaar des Godlijken Woorts te Stellenbosch".

Voor 1824 het die Kerk in die Kaapkolonie geressorteer onder die Klassis (Ring) van Amsterdam van die Hervormde Kerk van Nederland, die Reformatoriese Kerk uit die dae van die Kerkhervorming. wat toe nog onder verskillende name bekend was soos te vore aangetoon.

Dit is egter nie kommissaris De Mist wat self aan die bestaande Kerk in die Kaapkolonie die naam Hervormd gegee het nie. Inteendeel, die Kerk het homself so genoem.

Gedurende Desember 1803 het die kerkraad van die Evangeliese Lutherse Gemeente aan ..J. W. Janssens. Gouwerneur en Generaal en Chef; benewens Raaden van Politie aan die Kaap de Goede Hoop", 'n memorie gestuur oor kerklike aangeleenthede waarin gevra word vir vasstelling van hulle regte as Lutherse gemeente net soos by die "Hervormde gemeente" in gebruik. In hierdie stuk word gekla dat die Lutherse gemeente nie dieselfde regte het as die Hervormde gemeente nie en daarin verwys na ,eene op den 23 January 1781 in den Raad van Politie goedgekeurde overeenkomst, met den Eerw. Kerkenraad der Hervormde gemeente alhier treffende. ${ }^{20}$ ) Ook die Kerkraad van die Hervormde gemeente van Kaapstad het aan De Mist 'n memorie gestuur en wel op 9 April 1804. Dit begin as volg:

„Den kerkenraad der Hervormde gemeente deeser steede heeft ....."

en dit eindig met die woorde :

„Heyl en Eerbied, den Kerken-Raad der Hervormde Gemeente deeser steede ...."

Dit is dus nie Kommissaris De Mist wat op eie houtjie die Kerk aan .,de Kaap de Goede Hoop" Hervormd noem nie, maar dis die Kerk self. As gevolg van hierdie memorie het De Mist sy "Provisionele Kerken-Orde voor de Bataafsche Volksplanting aan de Kaap de Goede Hoop" opgestel. Artikel 20 lui :

„Het Hervormd Kerk-genoodschap bij verre het talrijkste, en ten platten Lande in deze Volksplanting het eenigste zijnde, behoeft overzulks bijzondere voorsieningen ....."

20) Boustowwe vir die Kerkgeskiedenis 1804-1836 deur A. Dreyer, Argivaris van die N.G. Kerk, bls. 4. 
Op 3 September 1804 kom daar van ,de Kerkenraad der Hervormde Gemeente in de Caabstad"21) 'n dankbetuiging aan De Mist. Op 19 November 1804 ontvang die Kerkraad die toestemming van die owerheid van ,,de gedane electie van den Kerkenraad der Hervormde Gemeente aan de Kaapstad tot Ouderling in dezelve gemeente den persoon van Johannes Mattheus Hertzog . ..."

By die vertrek van goewerneur Janssens stuur die Kerkraad van Stellenbosch aan hom op 6 Februarie 1806 'n dankbetuiging vir sy goeie dienste aan Kerk en staat. Hierdie brief begin as volg:

„Heer Generaal,

De Kerkenraad der Hervormde gemeente te Stellenbosch betreurd met zeer veel leedwezen Uw naderend vertrek" . . . . .

As die graaf van Caledon aangestel word as goewerneur aan die Kaap, dan haas "die Kerkeraad der Hervormde-Gemeente-alhier" om hom op 24 Mei 1807 geluk te wens met sy aanstelling.

As Sir David Baird op 5 April 1806 die kerkraad van die Kaapstadse Hervormde gemeente kennis gee van die aanstelling van ,,kommissarissen-politiek", dan kom daar 'n protes daarteen van die Kerkraad op 5 Mei 1806 waarin deur "de Kerkenraad der Hervormde Gemeynte aan deze hoofdplaats" nader informasie verlang word.

,te meer daar hij niet kan denken dat deeze aanstellinge geschied is op den ouden voet gelijk voor dezen, omdat zulks zou aanloopen teegen de origine van 't Politicque Commissariaat in de Hervormde Kerk - welk Commissariaat nimmers anders kan worden beschouwd, dan van 't jaar 1575 met de Hervormde Kerk, als de heerschende godsdienst in een onafscheidelijk verband te hebben gestaan, daar 't zelve vooral bij geleegenheyd van de geschillen in de Nederlandsche Hervormde Kerk tussen Remonstranten en Contra-Remonstranten is aangehouden ...."22) (Kursivering hier sowel as in die geval van die woord Hervormd ook elders van my, Joh. D.).

Op Sondag 9 Januarie 1814 is die Evangeliese Gesange in Kaapstad ,ingevolge het Besluit des Eerwaarden Kerkenraads . . . . by de Hervormde Gemeente alhier ingevoerd"'23) Omdat die Kaapkolonie in 1806 in Engelse hande oorgegaan het en daardeur die briefwisseling tussen die kerkraad van Kaapstad met die klassis van Hervormd Am-

21) Vgl. A. Dreyer, „Boustowwe vir die Kerkgeskiedenis”, bls. 28, 68, 72 en 79.

22) Boustowwe, bls. 88.

23) Ibid, bls. 141. 
sterdam en met die kerkraad in Batavia ,gestremd' is, het die kerkraad in korrespondensie probeer tree met die Hervormde Kerk in Londen.

Op 3 Augustus 1818 word daar dienaangaande 'n brief gerig deur "de Kerkeraad der Nederduitsche Hervormde Gemeente alhier", „aan Eerwaarde Kerkraad der Nederduitsche Hervormde Gemeente te Londen"24)

Hierdie voorbeelde waar die Kerk in die Kaapkolonie hom deurgaans Hervormd noem kan nog met talle ander aangevul word, maar miskien is dit nou genoeg hiervan en kan ons oorgaan na die eerste Sinodesitting aan die Kaap in 1824.

Die versoek aan die goewerneur om 'n Sinode te mag hou het op 19 Junie 1824 gekom van .J. H. von Manger, J. C. Berrangé en A. Faure. Predikanten der Hervormde Kerk".

In dieselfde versoek word ook gebruik gemaak van die naam „Hollandsche Gereformeerde Kerk" ${ }^{25}$ )

Die Kerkraad van Kaapstad het daarop 'n ,circulaire" gestuur „Aan de Buiten Kerken de aanstaande Synode betreffende", wat só begin :

„Wel Eerw. Heer en Verdere Broeders,

Nadat ingevolge Art. 46 van de voor de Hervormde Kerk binnen deze Colonie, vigerende Kerken-Ordre, de dato 25 July, 1804 op eene applicatie van het Kerkelijk Ministerie aan deze Hoofdplaats deswegens - door zijne Excellentie den Heere Hoofd Gebieder, verlof en authorisatie is verleend geworden, om eene Kerkelijke Vergadering van Predikanten en gedeligueerde Kerkeraadsleden, uit de gevestigde Hervormde Kerken Gemeente binnen deze Colonie . . . ." ${ }^{26}$ )

Beskrywingspunte is o.a. deur ds. A. Murray van Graaff-Reinet op 4 Okt. 1824 gestuur. Hiervan skryf ek hier punt 1 en 4 neer.

1. „Omtrent het doopen van kinderen wier ouderen aan de Hervormde Gemeente niet behoren."

en

4. .Of armen van andere geloofsgezindheden aanspraak hebben op die Kas der Hervormde Gemeenten?"

Op. 2 November 1824 is die sinode gekonstitueer. ${ }^{27}$ )

„De vergadering met het Gebed geopend zijnde convoceerde de Eerwaarde Praeses voor dezelve de Presente Afgevaardigden uit de onderscheidene Hervormde Kerken van de Colonie"28)

24) Boustowwe, bls. 145 .

25) Boustowwe, bls. 175, 176.

${ }^{26)-28}$ ) Boustowwe, bls. 179,187 en 203. 
Hierdie sinode het die eerste Kerkwet in Suid-Afrika opgestel. Die opskrif lui: „Algemeen Reglement voor het Bestuur der Nederduitsche Hervormde Kerk, in Zuid-Afrika, ontworpen in de Algemeene Kerkvergadering, gehouden binnen de Kaapstad op den 2de November en volgende dagen het jaar 1824."

Die eerste artikel lui :

„Het bestuur der Hervormde Kerk wordt uitgeoefend, Gemeentelijk, Ringsgewijs en Synodaal" ${ }^{29}$ )

Hierdie sinode het 'n Herderlike Brief aan die gemeentes gerig met die volgende aanhef : „Herderlijke Brief der Synode van de Hervormde Kerken, der Volksplanting aan de Kaap de Goede Hoop, aan alle Mede-christenen, inzonderheid die Leden hunner Gemeenten zijn:

„Geliefde Medechristenen! Zeer beminde Broeders en Zusters in den Heere!

Ruim zestig jaren zijn verloopen, sedert de laaste Algemene Vergadering onzes Hervormden Kerk-genootschaps heeft plaats gehad. Dezelve wierd toen gehouden, onder den naam eener gecombineerde Kerkvergadering ....."30)

Hierdie historiese feite, wat nog met tientalle aangevul kan word, laat geen twyfel dat die Kerk self hom Hervormd genoem het, ten spyte van die bewerings in die teendeel van hulle wat die naam Hervormd hand en tand beveg.

Die Kerk bly homself noem Hervormd tot in 1842. Die tweede Sinode het in 1826 saamgekom, ook as Nederduitsche Hervormde Kerk. 'n Reglement vir die ordening van sendelinge is opgestel waarin dit neergelê is, dat as iemand die eksamen om sendeling te word afgelê het, dan verkry hy die toestemming tot die bediening van die Heilige Sakramente onder vyf bepalings. In al hierdie vyf bepalings word die Kerk Nederduitsch Hervormd genoem bv.

a) „Dat hy. (die sendeling) in het algemeen als lid der Hervormde Kerk, zich zal moeten onderwerpen aan al de Wetten en Regulatien onder ons." ${ }^{31}$ )

As iemand aan al die vereistes voldoen het, ontvang hy die „Acte van Admissie" nl. „Alzoo voor de Synode der Nederduitsche Her-

29) Eeufeesalbum deur Prof. Dr. S. P. Engelbrecht, bls. 8, waar 'n fotografiese afdruk voorkom; verder Boustowwe, bls. 215-246.

30) Boustowwe, bls. 254.

31) Boustowwe, bls. 282, 283. 
vormde Kerken in Zuid-Afrika, vergaderd aan de Hoofdplaats van de Kaap de Goede Hoop is verschenen N.N. . . . ." ${ }^{32}$ )

Ook hierdie Sinode het 'n Herderlike Brief aan al die gemeentes opgestel op 15 November 1826:

„Herderlijke Opwekking van de Synode der Nederduitsche Hervormde Kerken in Zuid-Afrika, thans aan de Kaap de Goede Hoop vergaderd, aan al de Leden harer Gemeenten in het bijzonder . . .." ${ }^{33}$ )

Uit die baie voorbeelde waar die Kerk self hom Hervormd genoem het, noem ons nog :

„Redevoering van den opbouw der thans zoo voorspoedige Kerk der Nederduitsche Hervormde Gemeente aan den Wynberg, gehouden door wijlen den Wel-Eerw. Hr. M. Borcherds, in leven Predikant te Stellenbosch, op Zondag den 27 September 1829"34)

„Op Zondag den 21 April, werd de Weleerw. Hr. J. Pears in de Hervormde Gemeente van Albanie, door den Consulent, den Wel-Eerw. Hr. Morgan, bevestigd ...."35)

„Biddag - Op Donderdag den $16 \mathrm{Mei}$, word .... een biddag gevierd . . . . ook in de meeste Gemeenten der Hervormden in de Binnenlanden" ...." ${ }^{36}$ )

,Kerknieuws - Op den 15 July hebben zich bij den Actuarius Synodi gelegitimeerd als Predikanten der Hervormde Kerk in deze Volksplanting, de Wel-Eerw. Heeren P. B. Borcherds en A. F. du Toit ...." ${ }^{37}$ )

Toe die praeses van die eerste Sinode, ds. Berrange, oorlede is op 11 Maart 1827, het daar uit die pen van Ds. A. Faure, die praeses van die derde Sinode, 'n "In Memoriam" verskyn waarin die volgende staan :

„Die de overledene gekend hebben, zullen geredelijk erkennen dat hij, een verstandig aankleever was van de leer der Hervormde Kerk."

32) Ibid, bls. 284.

33) Ibid, bls. 287.

34) Het Nederduitsch Zuid-Afrikaansch Tijdschrift, 1839. bls, 133 v.v.

35) Tbid, 1839, bls. 239.

36) Ibid, 1839 , bls. 317 .

37) Ibid, 1839, bls. 404. Ds. A. Faure, dle Actuarius van die Kaapse Sinode, was die Redakteur van Het Nederduitsch Zuid-Afrikaansch Tijdschrift. 
Die een Sinode na die ander tot in 1842 het hom self genoem die Sinode van die "Nederduitsche Hervormde Kerk". So begin die moderatuursverslag van die derde Sinode op 12 Maart 1830 opgestel met die woorde:

„De ondergetekende Moderatoren der in November 1.1. gehoudene Algemene Vergadering der Hervormde Kerken in dit land ....."

en die kennisgewing i.s. die hou van die vierde Sinode in 1834 met die woorde:

„De Synode van het jaar 1862 besloten hebbende: Dat het Ministerie der Kaapstads Hervormde Kerk, verpligt zal zijn . . ." ${ }^{38}$ )

Hervormd as naam vir die Kerk in die Kaap lê gesaaid in die Acta en ander stukke van die Sinodes en in die verskillende kerklike publikasies van daardie dae. Maar vanaf die Sinode van 1834 begin die naam Gereformeerd meer as tevore gebruik te word. As tiperende voorbeeld wys ons op die ontwerp i.s. Sendinggenootskappe, ontwerp in die vierde Sinode nl. in 1834. Dit lui as volg:

"Ontwerp van bepalingen, belangende Hervormde Zendelings Genootschappen in de Nederduitsche Hervormde Gemeenten in Zuid-Afrika.

Art. 1. Gereformeerde Zendelings Genootschappen in de Nederduitsche Gereformeerde Kerken ....

Art. 3. Tot directeuren worden, bij voortduring, benoemd betrouwenswaardige leden der gemelde Gereformeerde Kerk . .." ${ }^{39}$ )

Dus Ned. Herv., Ned. Geref., en Geref. na mekaar.

Hierdie navorekom van die naam Gereformeerd het eindelik op die Sinode van 1842 daarop uitgeloop dat die naam Hervormd offisieël verander is in Gereformeerd. Dit het geskied op die 5 de November. In die konsep van die eerste Kerkwet het gestaan:

..Tot het Hervormde Kerkgenootschap behooren allen, die op belijdenis des geloofs tot ledematen zijn, aangenomen, dezulken die in de Hervormde Kerken gedoopt zijn, en degenen die in andere landen als tot het Hervormd Kerkgenootschap behooren $\ldots . .{ }^{40}$ )

38) Boustowwe, bls. 307 en 326.

39) Boustowwe, bls. 335 .

40) Prof. J. I. Marais : Gereformeerde Maandblad, Maart 1909, bls. 37, 38. 
In die notule van die Sinode staan:

"Tot de overweging der wetten overgaande, werd Art. 14 aangenomen, met uitlating van ,zoo wel als Synode” en „Hervormde” veranderd in "Gereformeerde" ${ }^{* 11}$ )

Soos Dr. Pretorius is ook Die Kerkbode verontwaardig dat van Hervormde kant volgehou word dat, soos die notule self duidelik leer, die naam in 1842 verander is. In sy uitgawe van 21 Maart 1951 staan:

„Ons moet dus andermaal besluit met die gevolgtrekking dat die 'bewyse' wat aangevoer is deur Die Hervormer nie bestaan nie en dat die hele konstruksie wat op die gang van ons kerkgeskiedenis geplaas word, so onwaar is (kursivering deur my, Joh. D.) as wat die poging ongelukkig genoem moet word .... Die hele voorstelling daar is onhoudbaar en dra 'n onmiskenbare kerkistiese stempel wat 'n mens teen elke prys moet vermy in ons kerkgeskiedskrywing".

Maar as ons voorstelling van die naamsverandering "onwaar" is, dan is ook die voorstelling van almal wat dit so stel dat die naam verander is, onwaar. Tevore is reeds daarop gewys dat ook Prof. S. du Toit in sy "Handleiding vir die studie van die Kerkgeskiedenis" leer dat die naam verander is, ook die Almanakke van die Geref. Kerk lees so $^{42}$ ) Hierdie voorstellings is dan ook "onwaar" en "onwaar" is ook die voorstelling van Prof. J. I. Marais, in lewe professor aan die Kweekskool in Stellenbosch, wat in sy "Geschiedenis der N.G. Kerk in Zuid-Afrika" dit op bladsy 162 ook leer :

„Het wetboek van 1842 verschilde op sommige belangrijke puntten van de tans door de Kerk erkende verzameling van Wetten en Bepalingen. De naam der Kerk werd veranderd".

Prof. Marais gee dan die konsep soos dit voor die verandering was, nl. „Hervormd" en vervolg dan:

"doch het werd gewijzigd, op voorstel van ds. H. A. Moorrees, zodat er te lezen stond: ,tot het Nederduitsch Gereformeerde Kerkgenootschap behooren allen die....."

Dan is die voorstelling van Ds. Moorrees, wat die voorstel tot naamsverandering in 1842 gemaak het, en dit in Het Volksblad erken

41) Eeufeesalbum van Prof. S. P. Engelbrecht, waar 'n fotografiese afdruk voorkom. De Handelingen der zeven Eerste vergaderingen van de Alg. Synode der Ned. Geref. Kerk van Z.A., bls. 197.

42) Almanak van die Gereformeerde Kerk 1939, bls, 32. 
het, ook „onwaar" en ook sy bewyse ,bestaan nie" en is ,onhoudbaar". Ons druk die brief hier af:

$$
\text { „Kruisvallei, } 28 \text { Apr. } 1866 .
$$

„Mijnheer, - In Uw geacht blad van eergisteren, Donderdag, den 26sten jongstleden, vind ik onder anderen van mij gezegd: „Dat het woord Nederduitsch Gereformeerd in het Kerkelijk Wetboek van mij afkomstig is". Het is zoo, in zooverre althans als in de Synode van 1842 het voorstel daartoe door mij is gedaan geworden. Dan, dit niet alleen, maar ook van mijn destijds uitgesproken gevoelen, wil ik tot op den huidigen dag geen jota teruggetrokken hebben; Want, ik geloof

1. De Nederduitsch Gereformeerde Kerk is eene Christelijke Kerk en als zoodanig kenmerkend onderscheiden van alle Joodsche, Mahomedaansche, en Heidensche Kerken;

2. De Nederduitsch Gereformeerde Kerk is eene Protestantsche Kerk en als zoodanig kenmerkend onderscheiden van de Roomsch en Griesch Katholieke kerken;

3. De Nederduitsch Gereformeerde Kerk eindelijk nog is al gereformeerd, kenmerkend onderscheiden van de Luthersche, Remonstrantsche, Doopsgezinde en zoo vele andere aansche en istische kerken, welke sedert de Hervorming in de Christelijke Kerk ontstaan zijn, en op den naam of rang van Hervormde Kerken even goed als de Nederduitsch Gereformeerde aanspraak maken kunne. - Door bovestaande, indien mogelijk, in uw eerstvolgend dagblad te plaatsen, zult gij verpligten, -

Uw dienstwilligen dienaar,

Moorrees.

(Ds. Moorrees schijnt ons te hebben misverstaan. Wat wij bedoelen te betoogen was dat de verandering van de oude benaming van "Hervormd" in die van "Gereformeerd" geheel onafhanklijk was van eenig denkbeeld alsof de laaste benaming eene regtzinniger kerk zou aanduiden dan de eerste. Het woord „Gereformeerd" schijnt reeds min of meer in spraakgebruik te zijn geweest toen de kerk nog officieel "Hervormd" werd genoemd. Maar er is nooit een gemotiveerd voorstel geweest om het eene woord door het andere te vervangen. Toe in 1842 het concept der Kerkelijke Wetten door de Synode werd herzien, heeft Ds. Moorrees eene wijziging in het eerste voorgesteld, en het is in die wijziging dat wij het eerst in een wetsartikel het woord "Gereformeerd" aantreffen. Maar dat Ds. Moorrees zelf de beide woorden als van eenerlei beteekenis aanmerkte blijkt genoegzaam uit zijn voorstel 
(blz. 197 en 198 der Handelingen) dat wij thans in zijn geheel opnemen:- (Gekursiveer deur my, Joh. D.)

,Tot het Nederduitsch Gereformeerde Kerkgenootschap behooren allen die op belijdenis des geloofs tot lidmaten zijn aangenomen: dezulken die in Nederduitsch Gereformeerde Kerken gedoopt zijn, en degenen die in andere landen als tot het Hervormde Kerkgenootschap behoorende erkend, zich hier te lande ter neder zetten, mits door behoorlijke bewijzen of attestatien van hunnen doop of lidmaatschap buitelands hebben doen blijken."

Dit is het voorstel zooals het oorspronkelijk staat en is aangenomen. Maar in het Wetboek zelf is het woord ..Hervormd" dat wij onderstreept hebben, ook "Gereformeerd" geworden.-Red. ..Volksblad"43)

Ons voorstelling van die verandering van die naam van die Kerk in die Kaap in 1842 sou dan „onwaar" wees, maar behalwe die Ned. Gereformeerde Professor Marais, Ds. H. A. Moorrees en die Ned. Geref. redakteur van Die Volksblad stem ook Eerw. A. Dreyer, gewese argivaris van die Kaapse Ned. Geref Kerk, en die Ned. Geref. predikant T. F. Burgers met my (en met die notule van die Sinode van 1842) in, dat die naam verander is. Eerwaarde A. Dreyer skrywe: ${ }^{44}$ )

.Die naam van de Kerk werd omtrent dezelfde tijd veranderd. De oude naam van 'Gereformeerde Kerken' in 1804 vervangen door "Hervormd Kerkgenootschap", werd door de Synode van 1842 verander in "Nederduitsch Gereformeerd Kerkgenootschap' ...." (Gekursiveer deur my. Joh. D.)

\section{Ds. Burgers skrywe : ${ }^{45}$ )}

.Als Hervormd uit de kolonie vertrokken, blijven verreweg de meesten hunner dat nog. Den mysterieuzen overgang van ,Hervormd' tot "Gereformeerd' hebben zij niet gemaakt".

Sou hulle voorstelling ook ,'n onmisbare kerkistiese stempel" dra?

Wellig is die naam in 1842 onder invloed van diz Skotse predikante verander. Die band met Nederland moes totaal gebreek word, blykbaar ook wat die naam betref. Tog is deur die pleitbesorgers van die nuwe naam Ned. Gereformeerd daar nie in geslaag om die liefde vir die naam Hervormd totaal uit te doof nie. Dit het voort geleef en is selfs in offisiële hoedanigheid gebruik tot in $1873 \mathrm{nl}$. in die Ondertekeningsformulier vir aankomende predikante.

43) Het Volksblad, 3 Mei 1866.

44) Eeufeest-Album van die Ned. Gereformeerde-Kerk in Z.A. bls. 93.

15) Schetsen uit de Transvaal, bls. 28. 
Hierdie Ondertekeningsformulier is belangrik. Daarin immers verbind elke ondertekenaar hom, as predikant van die Nederduitsch Hervormde Kerk, om die leer van die Kerk suiwer te verkondig en om alles in sy vermoë te doen om die belange van die Ned. Hervormde Kerk te behartig en te bevorder.

In hierdie so waardevolle dokumente noem die Kerk hom vanaf 1834 tot in 1873: Hervormde Kerk.

Hierdie Ondertekeningsformulier is in 1834 opgestel, is in 1838 deur 'n nuwe vervang wat onveranderd gebly het tot in 1873, dus tot dertig jaar na die naamsverandering in die Kaap. Die eerste begin as volg :

„Acte van Ondertekening van de Predikanten der Hervormde Kerk in Zuid-Afrika. ${ }^{46}$ )

Wij ondergeteekenden Predikanten der Hervormde Kerk van Zuid-Afrika verklaren in goeden gemoeden . . .."

Op 30 September 1834 het Ds. A. Faure en op 31 Augustus 1835 het Ds. H. A. Moorrees geteken as predikante van die Hervormde Kerk in Suid-Afrika. Is dit „onwaar", is dit "kerkisties"?

Dit is dus nie alleen ",sekere Hervormde" teoloë wat leer dat die Kerk in die Kaapkolonie eers in 1842 Ned. Geref. geword het nie. Van Ned. Geref. kant word dit ook so geleer.

Ook die Potchefstroomse Gereformeerde Professor J. P. Jooste leer dit. In sy proefskrif Die Verhouding tussen Kerk en Staat aan die Kaap tot die helfte van die 19de eeu skryf hy op bls. 218:

„Waar die Kerk aan die Kaap nie juis 'n offisiële naam ontvang het nie maar gedurende die jare 1665-1804 afwisselend gespreek word van die ware ,Christelike Gereformeerde Kerk' . . . en ook veral teen die end van die agtiende eeu van die 'Hervormde Kerk', word die naam in die studie soos volg gebruik: vir die tydperk 1665-1804, Gereformeerde Kerk; vir die tydperk van 1804-1842, Hervormde Kerk, en vanaf 1842, Nederduits-Gereformeerde Kerk".

Hy weet dus ook dat vanaf 1665 tot 1804 die Kerk ook Hervormd genoem is, al voeg hy dan ook daarby "veral teen die end van die agtiende eeu". Veral, dus nie alleen teen die end nie.

46) Prof. S. P. Engelbrecht: Eeufees-Album waarin twee fotografiese afdrukke hiervan verskyn. 
Die naam van die Kerk in Natal en in die Vrystaat. IN NATAL:

Toe die Voortrekkers in 1836 die Kaapkolonie verlaat het, was dit ses jaar voor die naamsverandering in 1842. Die naam van die Kerk was dus toe nog Ned. Hervormd. Hulle het as lidmate van hierdie Kerk die Kaapkolonie verlaat en hierdie kerknaam het op baie Voortrekkerattestate voorgekom. ${ }^{47}$ ) In Die Vaderland van 6 Oktober 1952 weet Dr. Pretorius te vertel :

„die meerderheid van die sertifikate het ongetwyfeld die benaming Gereformeerd daarop gehad".

Dit is bloot ' $n$ bewering, want alleen iemand wat al die attestate van die Voortrekkers, ook die wat nou nie meer bestaan nie, gesien het, sal kan sê watter kerknaam die meeste daarop voorkom. Dit lyk egter baie onwaarskynlik as 'n mens daarmee rekening hou dat die gemeentes in die Kaap toe nog Hervormd was, soos blyk uit die volgende :

„In de loop der 18de eeuw werd dit getal met nog vier vermeerderd (tevore was daar drie, Joh. D.) - te Zwartland, 1774; te Tulbagh, 1745; te Graaff-Reinet, 1792; en te Zwellendam, 1794. In het begin der $19 \mathrm{de}$ eeu, vóór de eerste Synodale Vergadering in 1842, zijn nog opgerigt de Hervormde Gemeenten te Caledon, 1810; te George, 1812, te Uitenhage, 1817; te Cradock, te Somerset en te Beaufort, 1818; te Worcester, 1820"..8)

Die laaste sinodesitting voor die Groot Trek wat in Junie 1834 gehou is, is nog gehou as 'n Sinode van die Hervormde Kerk, soos aangetoon in die vorige hoofstuk. Dat hulle dan nou voortaan ,hulle kerk nooit anders as (Ned.) Gereformeerd genoem" ${ }^{49}$ ) het nie, ,op een uitsondering na" soos Dr. Pretorius beweer, is tog sekerlik ondenkbaar. En hierdie bewering van hom word weerspreek deur die argief van die Ned. Geref. gemeente van Pietermaritzburg. Nieteenstaande hierdie bewering van Dr. Pretorius verwys hyself na die bevinding van Prof. Besselaar i.s. die verskillende kerkname in daardie argief. In hierdie lys kom die naam van die Kerk in Natal twaalf keer voor en vyf daarvan is Hervormd. Dit is deur Prof. Besselaar in Die Afrikaner van 11 Maart 1927 gepubliseer :

47) Prof. S. P. Engelbrecht: Eeufees-Album waar 'n fotografiese afdruk van so 'n attestaat voorkom.

48) De Handelingen van de Zeven eerste Vergaderingen van de Alg. Synode der Ned. Geref. Kerk in Z.A., bls. 111.

49) Die Afrikaner van 11 Maart 1927, No. 14, 15, 16. Die Vaderland, 6 Oktober 1952 . 
„Ons gee nou die twaalf verskillende name, waaronder ons gemeente in sy eie argief voorkom; ons het ons bes gedoen om kompleet te wees, maar het miskien een of meer onaangeteken laat verbygaan; bowendien is daar soveel argiefstukke, wat ontbreek, dat dit moontlik is, dat nog een of ander dosyn variante gebruik is.

1. Op die lys van intekening vir die bou van die Voortrekkerkerk (ongedateer) staan: Daar de Raad des Volks besloten heeft op die Plaats Pietermouritz Burg een gereformeerde kerk te stichten.

2. Op 'n bladversoekskrif, na ons voorkom van 1838 of 1839 , aan die kerkraad van Uitenhage, Graaff Reinet en Worcester om bewys van lidmaatskap van met name genoemde lidmate te wil stuur, staan in aanhef en ondertekening: Vanwege den kerkeraad der Nederduitsch Hervormde Gemeente alhier.

3. In ons trouregister teken Eerw. F. L. Döhne hom as : predikant van de Duitsch Gereformeerde Gemeente (hyself was 'n luterse sendeling.)

4. 29 April 1846 noem Eerw. Erasmus Smit hom in 'n petisie aan die Goewerment: Oud Leeraar bij de Nederduitsch Calvanistische Gerefformeerde kerk onder de Emigrante te P.M. Burg.

5. Inskrif in die nuut aangelegte Lidmateregister: Ledemaat Boek bevattende de Ledematen der Gereformeerde Gemeente te Pietermaritzburg, aangelegd den 4 October 1847.

6. Op 'n ongedateerde en ongetekende lys van 53 lidmate met besonderhede van name, deur wie aangeneem, waar, en op watter leeftyd, kom as opskrif voor; Leden van den Hervormde Kerk te Natal Umvoti.

7. 1855, in: Extract uit Kerkraadsnotuleboek: De Hollandsche Gereformeerde Kerk.

8. 1855 in 'n kwitansie: Nederduitsch Hervormde Kerk.

9. 21 Maart 1859 teken Eerw. D. Lindley, A.M. hom: Leeraar van de Hollandsche Gereformeerde Gemeente te P.M. Burg; die sertifikaat berus in die Trouregister.

10. In die notuleboek skrywe Ds. Huet nou eens: Kerkraadsvergadering, gehouden in de Consistoriekamer der Ned. Gereformeerde Kerk en dan weer.... der Geref. Kerk.

11. Op 'n kwitansie van 1862: De Nederduitsch Hervormde Gemeente dehet aan G. Worst. 
12. In 'n brief van Oud. Ferreira: aan de Eerw. Kerkraad der Nederduitsch Hervormde Kerk van P.M. Burg.

Ons kom nou nog by die Kaapse sustergemeentes, wat met ons gemeente onder dieselfde Kaapse Sinode ressorteer;

13. 11 September 1834 is 'n lidmaat-skapsertifikaat; in afwesigheid van die predikant, onderteken deur 'n onleesbare naam, met toevoeging van kwaliteit: Cassier-diaken, en dus miskien te verklaar uit mindere bedrewendheid in Kerkreg en Kerkgeskiedenis, as hy sê: Christelike Gereformeerde Kerk te Uitenhage.

14. 26 Februarie 1838: Hervormde Christelijke Gemeente te Uitenhage.

15. Op dieselfde dokument staan verder: Hervormde Christelijke Kerk (Alexander Smith).

1838, dito van Swellendam; dito, van Worcester, 1844 (Henry Sutherland).

16. 5 Mei 1840: Hervormde Gemeente van Graaff Reinet (A. Murray).

Vir 'n advokaat van kwaaie sake (Eng. Sea Lawyer) is hierdie Natalse Babiloniese spraakverwarring 'n saak om watertandend te betrag!

Volgens punte 14, 15 en 16 van hierdie lys, word die Kaapse gemeentes, vanwaar hierdie Voortrekkers hulle attestate gekry het, almal Hervormd genoem.

In die eerste koerant in Natal gepubliseer, ,.De Natalier en Pieter Maritzburgse Trouwe Aantekenaar", waarvan 'n eksemplaar in my besit is, kom daar ' $n$ kennisgewing voor in 1843:

.Getroud in de Nederduitsche Hervormde Kerk alhier door den Weleerw. Heer A. Faure ...."

Op 6 April 1852 met die Van Riebeeckfees op Pietermaritzburg is daar ' $n$ rede gehou deur die heer Marquard. Dit dra die opskrif :

„Feestviering gehouden in de Nederduitsche Hervormde Kerk te Natal ...."

Ook die latere Vrystaatse Staatspresident J. N. Boshoff, het 'n rede gehou, waarin die woorde voorkom:

„Als Hollandsche Volksplanters hebben onze voorvaders de eer gehad de werktuigen in Gods hand te zijn, om de Hervormde Godsdienst naar het zuider punt van Afrika over te brengen". 
In die Geslagsregister van die familie Bodenstein wat in hulle ou familie Bybel voorkom, word die Kerk in Pietermaritzburg Hervormd genoem :

.Johannes Casper Bodenstein (die latere Volksraadslid van Natal. Joh. D.) Geb. Beaufort West op 2 Aug. 1819. Lidmaat geworden van de Hervormde Kerk te Weenen op 21 Mei 1841, door de Eerwaarde Heer Lindley".

en van C. J. Bodenstein, geb. 4 November 1826 :

„Lidmaat geworden 1842 van die Hervormde Kerk, Pietermaritzburg".

Die Hollander Erasmus Smit gebruik by voorkeur die naam Gereformeerd, maar tog skryf hy dat die "Algemene Kerkelijke Reglement" van die Ned. Hervormde Kerk wat in 1824 in Kaapstad opgestel is, die Kerkwet van Natal is.

Om kortliks op te som: Die „Natalier en Pietermaritzburgse Trouwe Aantekenaar"; die heer Marquard; die later president Boshoff; die geslagregister van die Bodensteins, die Kerkraad van Pietermaritzburg in 1838 of 1839; ' $n$ kwitansie in 1855 en een in 1862 offisieel namens die Kerkraad; oudl. Ferreira en soos Dr. Pretorius dit stel: 53 ,individue" almal Natalse Voortrekkers van dié tyd, noem die Kerk almal Nederduitsch Hervormd maar teen hulle almal in, sê een ,individu", Dr. Pretorius in 1952 dat "die Voortrekkers op een uitsondering na hulle kerk nooit anders as (Ned.) Gereformeerde genoem het nie".

Die Hollander, eerw. Erasmus Smit, wat soos die Hollanders Ds. Frans Lion Cachet, en Ds. Huet voorkeur gegee het aan (Ned.) Gereformeerd, gebruik ook wel die naam Hervormd al is dit dan ook saam met Gereformeerd. Op 11 Junie 1937 skryf hy van ,de Hervormde Gereformeerde Nederduitsche Geloofsbelydenis" ${ }^{30}$ ).

\section{IN DIE VRYSTAAT.}

Dr. Pretorius beweer dat ek ,weer 'n poging aanwend om 'n baie belangrike historiese oorkonde eenvoudig opsy te skuif", omdat dit nie in sy kraam pas nie. Dit is die Doopregister van Winburg. Dit sou vir my "as historiese stuk geen betekenis hê nie," en ek begaan die ergerlikheid om my lesers ,onder die indruk te bring dat die Kerk in die Vrystaat Hervormd genoem is tot in Mei 1867". 
Die eerste twee opmerkings is maar weer veronderstellings van Dr. Pretorius. In die derde geval egter vertolk hy my volkome korrek. Maar ek hoef geen moeite te doen om my lesers onder hierdie indruk te bring nie, die offisiële stukke doen dit self.

As die Voortrekkers oor die Oranje rivier die Vrystaat binne trek, dan is hulle nog lede van die Hervormde Kerk. As hulle hul eerste grondwet in 1854 opstel, dan lê hulle in Artikel 24 neer:

„Die Ned. Hervormde Kerk zal door den Volksraad bevorderd en ondersteund worden". ${ }^{51}$ )

Niemand het hierteen beswaar gehad nie. Die Vrystaatse predikante was nog almal aan die Kaap gelegitimeer as predikante van die Ned. Hervormde Kerk. Die name Hervormd en Gereformeerd was vir die Voortrekkers van gelyke betekenis en niemand het behoefte gehad om die ou naam Hervormd te vervang nie.

Op 25 Februarie 1864 maak die Vrystaatse Volksraad 'n onderwyswet en bepaal daarin dat die „Predikant der Nederduitsch Hervormde Kerk" lid van die plaaslike skoolkommissie moet wees. En op 17 Februarie 1865 besluit dieselfde Volksraad dat waar daar geen skoolkommissies is nie, die bestuur by die landdrost ,,den Leeraar der Nederduitsch Hervormde Kerk" en 'n ouderling sal berus. En let wel, hierdie Vrystaatse Volksraad het vir die oor- en oorgroot meerderheid bestaan uit Boere wat almal lid van die Vrystaatse Kerk was. Maar, die kerknaam was toe nog nie 'n ,kwessie" nie..

Dit sou egter op die lang duur nie so bly nie. Die invloed van die Kaapse Sinode en van die Skotse predikante sou deurwerk. Die naam Ned. Gereformeerd wat vanaf 1842 die offisiële naam van die Kerk in die Kaapkolonie geword het, het almeer ingang ook in die Vrystaat gevind. In 1866 is die eerste poging aangewend deur Ds. v. d. Wall en twintig ander om die naam in die grondwet verander te kry in Ned. Geref..$^{52}$ ) Dit is egter deur die Volksraad geweier. Die volgende jaar is daar egter in geslaag toe die voorstel „van den heer G. Visser ondersteund door den heer $T$. de Villiers" om die naam van die Kerk te verander aangeneem is. Die Notule lui :

„Dat in Art. XXIV der Constitutie Hervormde Kerk wordt verander in Gereformeerde Kerk"s3)

Hierdie feit kan net so min ontken word as die naamsverandering in 1842 in die Kaapkolonie.

s1) Sien fotografiese afdruk in Eeufees-Album deur Prof. S. P. Engel-

52) en 53) Sien fotografiese afdruk in Eeufees-Album deur Prof. S. P. Fingelbrecht. 
Ook van die kant van die Afgeskeidenes is die Kerk in die Vrystaat Hervormd genoem. So doen die heer J. J. Venter in 1858, ${ }^{54}$ ) nadat hy die band met die Vrystaatse Kerk verbreek het. Hy skryf daaroor :

„Ik heef in die maand January 1858 de leeraar en Kerkenraad bedanken en heef hun 5 punten in geschrift voorgelegd waardoor ik hun als ontrou aan die nederlands hervormde kerkbestuur en den hijlige bijbel verklaard heef ...."

Die Kerk self sou hom in die Vrystaat nooit anders as Gereformeerde of Ned. Gereformeerd genoem" het nie, so skryf Dr. Pretorius, maar self beweer hy dat Ds. Lindley die doopregister ,in 1842 op Winburg aangelê het onder die benaming Gereformeerd Christelike Kerk". Dus nie Gereformeerd nie en ook nie Ned. Gereformeerd nie. soos hy bo beweer.

\section{Die NaAm van die Kerk in Transvaal.}

Toe die Voortrekkers oor die Vaalrivier getrek het, was die naam van die Kerk in die Kaapkolonie nog offisieël Nederduitsch Hervormd soos sy Kerkwet (1824) sy Legitimasieakte en ander stukke getuig. Eers ses jaar later en wel in November 1842 sou die naam aldaar verander word. Agt maande voor hierdie naamsverandering word die eerste Voortrekkergemeente in Transvaal gestig t.w. die Ned. Hervormde Gemeente van Potchefstroom. 'n Kerkgebou was daar toe nog nie. Wel is die vorige jaar 'n kollektelys rondgestuur om gelde in te samel vir hierdie doel.

Hierdie gemeente is gestig deur Eerw. Daniel Lindley, die Presbiteriaanse sendeling uit Amerika wat eers onder die Soeloes en ná die nederlaag van Dingaan onder die Voortrekkers in Pietermaritzburg gearbei het. Dit is gedoen in opdrag van die Volksraad in Natal. maar sonder dat hy instruksies ontvang het wat die naam van die gemeente in Potchefstroom of in Winburg moes wees. Daar was nog geen Cachet om die naam van die Kerk 'n twisappel te maak nie. Die name Hervormd en Gereformeerd het toe nog dieselfde betekenis en inhoud gehad en is albei deur die Voortrekkers gebruik. Dat hulle „vandat hulle die Kolonie verlaat het nooit die benaming .Hervormd" vir hulle Kerk gebruik het nie, behalwe in die meervermelde kollektelys van $1841^{\prime \prime}$, soos Dr. Pretorius skryf, ${ }^{55}$ ) is in die vorige hoofstuk duidelik

54) Vgl. sy brief aan J. van Andel op 10 Maart 1858 in Geskiedenis van die Ned. Hervormde Kerk van Afrika deur Prof. S. P. Engelbrecht, 3e druk, bls. 149.

s5) Die Vaderland, 6 Oktober 1952. 
met die nodige historiese feite weerlê. Dat daar nie net een uitsondering in Transvaal is nie, sal verder blyk. En as die eerste kollektelys in Transvaal opgestel word, dan is daar geen Hollander wat "Hervormd" daarop skryf nie, maar die Voortrekkers doen dit self. Dit is gerig aan :

"Waarde Broeders en Landsgenooten en mede leematen der Hervormde Kerken benevens alle Christelike Kerken van Zuid-Africa".

en onderteken o.a. deur „Potgieter, Comandant”, P. J. van Stade Kerkraad"; G. J. Kruger Velcornet", G. S. Maree".

In die notuleboek deur Ds. Dirk van der Hoff aangelê op Potchefstroom in 1853 staan voorin te lees:

„Handelingen van de Kerkvergadering van de Nederduitsch Hervormde Gemeente te Potchefstroom".

Die opstelling van die eerste grondwet het plaasgevind in 1855 . Die opsteller was Jacobus Stuart, die seun van 'n Amsterdamse predikant maar nie van die Hervormde Kerk in Nederland nie, maar van die „Remonstrantsch Gereformeerde Kerk" aldaar. Let wel, van die Remonstrantse Kerk. Hy het die ontwerp opgestel saam met 'n kommissie van die Volksraad, waarvan Paul Kruger, wat toe nog wel Hervormd was, ook lid was. $\mathrm{Na}$ die opstelling is die konsep goedgekeur op verskillende volksbyeenkomste wat gehou is deur kommandant generaal M. W. Pretorius en Ass. Kommandant generaal T. F. Dreyer en daarna is dit op 'n Volkskongres op 16 Des. 1856 op Potchefstroom aangeneem. En hiermee het die volk as sodanig vir die naam „Hervormd" gekies.

In hierdie grondwet art. 23 word bepaal :

„Het volk wil zijne Nederduitsche Hervormde Godsdienstleer, zoo als deze in de jaren 1618 en 1619 door de synode te Doredrecht is vastgesteld, behouden."

Art. 25 lui :

„Het zal geene andere vertegenwoordigers in de Volksraad aanstellen, dan degenen die lidmaten der Nederduitsch Hervormde gemeente zijn".

In die gewysigde grondwet van 1858 lui Art. 20 as volg:

„Het volk wil zijn Nederduitsch Hervormde Godsdiensleer... . en de Nederduitsch-Hervormde Kerk zal de Kerk van de Staat zijn". 
Die grondwet is nie sommer haastig goedgekeur nie. Behalwe die volksbyeenkomste van 1856 het die Volksraad „volle drie uren" daaroor beraadslaag. Na ryp beraad dus het die volk self en ook sy Volksraad beslis vir die naam Hervormd gekies.

Op die voetspoor van Ds. Frans Lion Cachet wil Dr. Pretorius nie weet van die naam Hervormd nie. Maar die ou Transvalers het egter die naam liefgehad.

Toe Ds. Cachet kerklik Transvaal in beroering gebring het met sy getwis oor die kerknaam, het daar 'n memorie uit Rustenburg onderteken deur 26 persone by die Uitvoerende Raad in Pretoria aangekom, waarin daardie ou Voortrekkers dit opneem vir die goeie reg van die naam Hervormd. Die eerste ondertekenaar, "oudouderling" P. J. van Staden, was een van die eerste sewe Kerkraadslede wat deur eerw. Daniel Lindley in Maart 1842 met die stigting van ons eerste Voortrekkersgemeente op Potchefstroom in hulle ampte bevestig is. Die memorie lui as volg : ${ }^{56}$ )

„Rustenburg,, 19 September 1866.

Aan zijn Hoog Edle de President M. W. Pretorius en Leden van de Uitvoerende Raat, van den Z.A. Republiek.

\section{Hoog Edele Heren}

Wij den ondergetekenden ledematen van den Nederduytsch hervormde Kerk, acht ons verpligt onzen standvastigen gevoelentheid en de welwillige hanthaving der zelven aan u Hoog Edl. bekend te stellen van onzen Nederduytsche hervormde godsdienstleer, alwaar ons geleert worden en opgegeven worden in den heidelbergschen catechismus, en wij wens verder de opbouwen en hanthaven van Art. 24 der grondwet. Wij geeft ook onzen misnoegens en speid onser allerharte aan U Hoog Edle, te kennen, over die zoogenaamde Caseet, die nu voor de Achtbare volksraat geplijt heeft, en die getragt heeft zoo wij vernome heeft om geestelijke zaken tot polletieke zaken te verdraaeyen, indien het zoo zouden wezen, zouw hij juyst bekwaam wezen om de zwaart over het land te bringen, ten twede moet wij u Hoogedle herrindere toen wij onsen moedersland verlaten heeft dat onsen Kerk die de zoogenaamde Caseet veracht en schandelijk en listig tegen werk geen andere naam hat dan Nederduyts hervormde Kerk. - waar onder wij ook gedoopt zijn en onzen belijdenis des geloofs heeft afgelegt. nu wort u Hoogedle Eerbiedig gevraagt, van waar kombt die zoogenaamde Caseet, wie is hij en wat is hij, die ons land beroer en ons regering verswak, HoogEdle Heren onser allerharte spreek

56) 'n Fotografiese afdruk verskyn in die Eeufees-Album deur Prof. S. P. Engeibrecht. 
tot $\mathrm{u}$ Hoog Edles met innige belangstelling over onzen godsdiensleer, zoo als ons geleert wort en opgegeven worden in heidelbergschen Catechismus, ook over een kombs onzer geloofsbelijdenis, wij wens ook u Hoog Eds. ter herrinering te bringen te onderzoek of die zoogenaamde Caseet de grondbeginsel bezit van Art. 28 onser geloofsbelijdenis. $W_{i j}$ den ondergetekende verzoek eerbiedig aan u HoogEd. ook deze stuk voor die Achb. Volksraat te lezen, en verzoek u Hoog Edle de President M. W. Pretorius voor ons te spreken voor den Achtb. Volsraat over onzen Wet indien er bij de make van onzen wet geen gaten in gebleven is waar inkruypers, uit en in kan kruyp dan het zoo spoedig toe te stop mogelijk is.

Dit is onze aller hartewins en beveel het verder in $u$ Hoog Eds. handen met de hulp en genade des Heren.

Wy noem ons u Hoog. Eds. dienswillige dienaren.

P. J. van Staden outouderling, Jan Viljoen de oude, E. A. Hanna. D. A. van Stade, J. .J. v. d. Merwe, D. S. v. d. Merwe, P. J. A. Haarhoff, D. S. v. d. Merwe, M. P. van Stade de oude. Christiaan van Stade, Gerhardus van Coppenhagen, H. J. van Stade, P. Nyhoff, P. J. Breet, Hellen Webb, M. M. M. Raus, J. J. Raus, W. M. Webb, Joh. McDonald, G. van Rooyen, G. Breet, H. P. v. d. Merwe. P. J. Booyzen, J. A. Esterhuyse, H. N. Ras, L. v. d. Westhuissen.

Die Kerk deur Ds. Cachet in Transvaal gestig is egter nie deur die Uitvoerende Raad erken nie, soos blyk uit die antwoord: ${ }^{57}$ )

Gouvernementskantoor Pretoria 7 Dec. 1866.

Weled. Heer P. J. van Staden oud ouderling en anderen Rusten burg.

Weled. Heer,

In antwoord op U Ed. memorie dd. Rustenburg 19 September 1866, diene in antwoord, dat noch de Kerk, noch Lion Cachet. als Predikant door de Regering der Z. Afr. Republiek erken wordt.

By order

(Get.) J. W. SpruYt.

Gouvts. Secretaris.

Dr. P. herhaal sy bewering, dat die Voortrekkers op een uitsondering na nooit die woord Hervormd sou gebruik het nie, op bl. 17 van sy brosjure waar hy skryf :

57) Hervormd Teologiese Studies, Aug. 1953, bls. 290-292. 
„Reeds in 1942 het ek geskryf dat die Voortrekkers net eenmaal die naam Hervormd gebruik het. Dit is nou bevestig deur die ondersoek van $\mathrm{dr}$. Scholtz, en ook deur 'n ander vooraanstaande geskiedskrywer wat jare in die Staatsargief gewerk het en die stukke van die Staatsekretaris van hierdie tydperk noukeurig deurgewerk het."

Wie hierdie geheimsinnige "vooraanstaande geskiedskrywer" is, steek Dr. Pretorius vir sy lesers weg. Maar wie hierdie onbekende skrywer ook al mag wees op wie Dr. Pretorius hom beroep, die Voortrekkers het hulle voorkeur vir die ou kerknaam Hervormd nie losgelaat nie, soos uit die bostaande memorie e.a. stukke blyk. Die stelling van Dr. Pretorius c,s. word ook weerspreek deur die volgende stuk uit daardie jare van stryd oor die kerknaam:

\section{"Hervormd" en "Gereformeerd".}

„Ds. Cachet is op de ,algemeene kerkvergadering der Herv. Kerk in de Z.A. Republiek" in Nov. 1l. gehouden onder anderen erg te velde getrokken tegen hetgeen hij de naamsverandering noemt van de Transvaalsche Kerk, die hij zegt "Gereformeerd" had moeten zijn in plaats van "Hervormd", zooals de Hollandsche liberale kerk zich noemt. Als hij de in 1859 gedrukte "Handelingen der zeven eerste Vergaderingen van de Algemene Synode der Nederduitsch Gereformeerde Kerk van Zuid Afrika" nagaat, zal hij zien dat zijne beschouwingswijze ten dezen opzigte geheel verkeerd is. Hij zegt (pag. 16 zijner brochure):-

„De oude emigranten die meer dan dertig jaren geleden de Kaapkolonie verlieten, zetteden zich neder in Natal, Orange Vrijstaat en Zuid-Afrikaansche Republiek, als leden eener kerk die den naam droeg van "Nederduitsch Gereformeerde Kerk" van welke zij leden waren."

Hoe verkeerd hij hieromtrent ingelicht is blijkt uit het volgende hoofd geplaatst boven de Beschrijvingspunten van 1837, dus nog geen dertig jaren geleden:-

,Beschrijvingspunten, geredigeerd door het Eerwaarde Ministerie der Nederduitsch Hervormde Kerk in de Kaapstad, voor de op 17 October 1837, en volgende dagen te houden Extraordinaire Synodale Vergadering".

De uitgewekenen dus, die meer dan dertig jaren geleden zich in Natal, den Oranje Vrijstaat en de Transvaal nederzetteden, deden niets meer dan den naam te behouden waaronder $z i j$ in de kolonie bekend waren. Van eene naamsverandering kan er dus 
onmogelijk sprake zijn, en geen wonder dat men tevergeefs de boeken er op heeft nageslagen om te zien op welk gezag "Gereformeerd" in "Hervormd" is veranderd.

Zelfs in de beschrijvingspunten van 1842, hoewel het hoofd slechts de woorden bevat ,geredigeerde voorstellen voor de Synode, welke op 1 November aanstaande zal worden gehouden", wordt geen enkele maal het woord "Gereformeerd" gebruikt, terwijl de benaming "Hervormd" herhaaldelijk door leden der verschillendste rigtingen in hunne voorstellen wordt gebezigd.

Uit genoemde „Handelingen” echter blijkt, dat men vóór dien tijd beide benamingen heeft gebruikt, als hebbende eenerlei beteekenis, en dat het denkbeeld alsof de twee benamingen verschil van beginselen aanduidden in de hersens van geen enkel lid is opgekomen. Ds. van der Lingen schijnt zich het eerst van het woord "Gereformeerd" bediend te hebben; maar tot op 1842 bezigden Di. A. Faure, P. E. Faure, Robertson en andere predikanten, wier regtzinnigheid buiten alle kwestie is, in den regel het woord "Hervormd", terwijl Ds. H. Moorrees, wiens vrijzinnigheid ook niemand zal betwisten, de eerste schijnt geweest te $z \mathrm{ijn}$, die in eene verandering van een wets-artikel het woord "Nederduits Gereformeerd" heeft gebezigd, waar door hem werd voorgesteld „, dat (zie Art. 197 der „Handelingen",) men inplaats van art. 1 te lezen zoo als gedrukt, leze: Tot het NederduitschGereformeerde Kerkgenootschap behooren allen die op belijdenis des geloofs tot lidmaten zijn aangenomen; dezulken die in Nederduitsch Gereformeerde Kerken gedoopt zijn", enz. Daarna werden op verscheidene plaatsen Hervormd in Gereformeerd veranderd. zonder dat het blijkt dat men daarmede iets anders bedoelde dan om eenvormigheid van benaming te bekomen. Men ziet dan ook verder spreken van de "Gereformeerde Kerk in Holland" en van „buitenlandsche tot de Gereformeerde Kerk behoorende Hooge scholen". wanneer men sprak van de Nederlandsch Hervormde Kerk en daarmede in verband staande akademien.

Uit dit een en ander blijkt genoegzaam dat Ds. Cachet het geheel mis heeft, wanneer hij meent, (zoo als het blijkt dat hij meent) dat de Transvaalsche kerk den naam van Hervormd heeft aangenomen na hare afscheiding van de Kaapsche kerk. De naam van Nederduitsch Hervormd was de naam waaronder de leden der Koloniale kerk algemeen bekend waren toen de emigratie plaats vond, en het kan dus geen verwondering baren, dat de kerk aldaar onder die benaming in de Grondwet bekend staat. En daar het uit het hierboven aangehaalde duidelijk is dat die benaming 
in de Koloniale Kerk voor "Gereformeerde" heeft plaats gemaakt. zonder dat het blijkt dat er in het geheel aan gedacht is om daarmede eene meerdere mate van regtzinnigheid voor de Kaapsche Kerk aan te duiden, of dat men er eenig ander bepaald doel mede voorhad, kon men nauwelijks verwachten dat de Transvaalsche Kerk van zulk eene verandering, als in zich zelve niets beteekenende, notitie zou nemen." ${ }^{8}$ )

"Net eenmaal" sou die Voortrekkers volgens Dr. Pretorius die naam Hervormd gebruik het. Dit word weerspreek deur die notuleboek van Potchefstroom 1853; die grondwet van 1856; die volksbyeenkomste in verband met die goedkeuring daarvan; die volkskongres op Potchefstroom; die gewysigde grondwet van 1859; die memorie uit Rustenburg met 26 handtekeninge; die brief van die ..gouvts. secretaris" J. W. Spruyt; „Het Volksblad” van 26 April 1866, om van andere kerkstukke te swyg. En was hierdie mense wat vir die bostaande stukke verantwoordelik was, nie Voortrekkers nie? ${ }^{59}$ ) Kom onder hulle nie vooraanstaande persone voor nie? So kom onder die lede van die kommissie wat die konsep van die eerste grondwet opgestel het, die name voor van Paul Kruger, die latere Staatspresident, H. S. Lombardt, die bekende Potchefstroomse ouderling, G. J. Kruger, die oom van President Kruger, en die sprekers op die volksbyeenkomste om die grondwet goedgekeur te kry nl. die laaste President M. W. Pretorius en Ass. generaal T. F. Dreyer, terwyl onder die memoraliste uit Rustenburg die naam voorkom van die Voortrekker-ouderling, P. J. van Staden. Hulle verkies almal Hervormd.

Van Hervormde kant is nie beweer dat die naam Ned. Geref. nie ook gebruik is in baie stukke nie. Dit is Dr. Pretorius wat nie daarvan wil weet nie dat Hervormd en Gereformeerd albei gebruik is. Ja hy gaan selfs so ver om op bls. 17 te skryf dat dit 'n klug is: „Wat 'n klug dus die bewering dat die Voortrekkers die name deurmekaar gebruik het".

Maar dit is nie as 'n klug beskou deur die Algemene Kerkvergadering in Transvaal nie, wat soms skryf Ned. Hervormd en soms Ned. Gereformeerd. Dit is nie 'n klug beskou selfs deur die bestryder van die naam Hervormd, nl. Ds. Frans Lion Cachet nie wat homself in 1862 in 'n brief aan die Regering van die Suid-Afrikaanse Republiek noem .Waarnemende consulent der Nederduitsche Hervormde Gemeente van Utrecht" en in dieselfde stuk ook gebruik maak van die naam Ned. Gereformeerd. Dit is nie as 'n klug beskou toe die kerkraad

58) Het Volksblad, 26 April 1866.

59) Ons Kerknaam, bls. 3. 
van Utrecht waar Ds. Cachet konsulent was aan die fungerende staatspresident van die Suid-Afrikaanse Republiek geskryf het:

.Ten deze opsigte verzoeken wij U Hoog Ed. eerbiedigde geme(e)nte in dit district toegestaan eene Leer(aar) der Ned. D. Hervormde Kerk volgens Art. 227 der Grondwet te beroepen"60)

Dat in 1842 geen Ned. Geref. gemeente op Potchefstroom gestig is nie, maar eers in 1866 deur die bemoeiinge van Ds. Cachet, blyk dit uit die volgende Ned. Geref. stukke :

.1849 Potchefstroom gestig"61) (Ned. Geref.)

"1866 Stigting Ned.. Geref. Kerk in Transvaal". ${ }^{62}$ )

„In 1866 werd de Nederduitsche Gereformeerde Kerk van de Transvaal gesticht". ${ }^{63}$ )

„.Die Ned.-Geref. Kerk . . . in die SuidAfrikaanse Republiek . . . . in 1866 onder 'n eie Sinode tot selfstandigheid gekom het onder leiding van Ds. F. Lion Cachet van Utrecht". ${ }^{61}$ )

"Na Tagtig jaar (1849-1929)" G. D. Worst. ${ }^{63}$ )

As in Ned. Geref. gemeente in 1842 of selfs in 1849 gestig is, dan kan dieselfde gemeente en ook daardie Kerk nie weer in 1866 gestig word nie.

As slotbeskouing van hierdie studie kom ek in 'n korte samevatting tot die volgende resultaat:

dat die baie "nooits" wat Dr. Pretorius uitspreek t.o.v. die kerknaam Hervormd nie een steekhoudend blyk te wees nie, nie in Nederland voor 1796 nie in ons eie land nie en ook nie onder die Voortrekkers nie;

dat kerkhistorici van sy eie Ned. Geref. Kerk op hierdie punte dikwels nie met hom instem nie, soos bywoorbeeld Dr. A. Dreyer, die gewese argivaris van die Kaapse Kerk en ook ander Ned. Geref. skrywers oor die kerkgeskiedenis soos Prof. I. J. Marais, Dr. de Wet en Dr. J. J. Kotze, asook Ds. T. F. Burgers, en Dr. Hanekom;

dat bv. Dr. A. Dreyer dikwels van Dr. Pretorius verskil omdat eersgenoemde objektief teenoor sy stof staan en die Hervormde Kerk nie alles wil ontsê nie, terwyl laasgenoemde subjektief staan en ook apologeties skryf soos bv. blyk uit die gebruik wat hy van die bevin-

60) S. A. Argiefstukke, Transvaal No. 4, bls. 549.

61) Jaarboek van die Ned. Geref. Kerke in S.A. 1934, bls. 266.

62) Jaarboek van die N.G. Kerke. Baie jaargange, bv. 1940, bls. 71 .

63) Korte schetsen uit de Geschiedenis der Ned. Geref. Kerk in S.A. deur A. Dreyer, Hoofstuk XIV.

61) Eerw. A. Dreyer: Die Voortrekkers en hul Kerk, bls. 119.

65) Vgl. Die Hervormer, 30 Oktober 1940, bls. 22 en 23. 
ding van Prof. Besselaar uit Die Afrikaner van 11 Maart 1927 gemaak het in Die Vaderland van 6 Oktober 1952, en uit sy smalende opmerking oor die Hervormde "kollektelysie" en soos verder blyk uit sy lelike beskuldigings, wat grens aan laster, as hy voorgee dat met die uitstalling van historiese dokumente tydens die eeufees van die Hervormde gemeente van Potchefstroom in 1942, ,die voorblad van die doopregister toegeplak was," omdat ek geen "sterk saak" sou hê nie en daarom blykbaar iets wou wegsteek. Maar netsomin as wat die Hollander Ds. Frans Lion Cachet, dit reggekry het om die kerknaam Hervormd onwettig verklaar te kry en die ,nooit-cachet", die ",nooitstempel", daarop gedruk te kry, netsomin sal die Afrikaner Dr. Pretorius, die voortsetter van hierdie poging van Ds. Cachet, daarin slaag om die naam Hervormd wat "so sterk en so ingewortel was" ${ }^{66}$ ) vanaf die dae van die Kerkhervorming in Nederland, in die Kaapkolonie lank voor 1802 en by die Voortrekkers in Vrystaat, Natal en Transvaal, onwettig verklaar kry.

JOH. DREYER. 